\title{
The System Beryllia-Alumina-Titania: Phase Relations and General Physical Properties of Three- Component Porcelains ${ }^{1}$
}

\author{
S. M. Lang, C. L. Fillmore, and L. H. Maxwell
}

\begin{abstract}
The data obtained in the investigation of the phase equilibria in the systems berylliaalumina, beryllia-titania, and alumina-titania suggest that the published equilibrium diagrams of these systems need to be revised: the system $\mathrm{BeO}-\mathrm{TiO}_{2}$ shows no compounds, an eutectic at about 85 weight percent of $\mathrm{TiO}_{2}$ and $1,670^{\circ} \pm 3^{\circ} \mathrm{C}$, and an area of $\mathrm{TiO}_{2}$ solid-solution. The system $\mathrm{BeO}-\mathrm{Al}_{2} \mathrm{O}_{3}$ has three eutectics: (1) at $1,890^{\circ} \pm 10^{\circ} \mathrm{C}$ and about mole ratio $1 \mathrm{BeO}$ : $4 \mathrm{Al}_{2} \mathrm{O}_{3}\left(94.2 \% \quad \mathrm{Al}_{2} \mathrm{O}_{3}\right) ;(2)$ at $1,850^{\circ} \pm 10^{\circ} \mathrm{C}$ and about mole ratio $2 \mathrm{BeO}: 3 \mathrm{Al}_{2} \mathrm{O}_{3} \quad(85.9 \%$ $\mathrm{Al}_{2} \mathrm{O}_{3}$ ); and (3) at $1,835^{\circ} \pm 10^{\circ} \mathrm{C}$ and about 75 weight percent of $\mathrm{Al}_{2} \mathrm{O}_{3}$, and two congruently melting compounds, $\mathrm{BeO} .3 \mathrm{Al}_{2} \mathrm{O}_{3}\left(92.4 \% \mathrm{Al}_{2} \mathrm{O}_{3}\right)$ at $1,910^{\circ} \pm 10^{\circ} \mathrm{C}$ and chrysoberyl (BeO.$\mathrm{Al}_{2} \mathrm{O}_{3}-80.3 \% \quad \mathrm{Al}_{2} \mathrm{O}_{3}$ ) at $1,870^{\circ} \pm 10^{\circ} \mathrm{C}$. The system $\mathrm{Al}_{2} \mathrm{O}_{3}-\mathrm{TiO}_{2}$ has two eutectics: (1) at $1,705^{\circ} \pm 5^{\circ} \mathrm{C}$ and about 20 weight percent of $\mathrm{Al}_{2} \mathrm{O}_{3}$; and $(2)$ at $1,840^{\circ} \pm 10^{\circ} \mathrm{C}$ and about mole ratio $5 \mathrm{Al}_{2} \mathrm{O}_{3}: 4 \mathrm{TiO}_{2}\left(61.5 \% \mathrm{Al}_{2} \mathrm{O}_{3}\right)$, and a high- and low-temperature form (alpha and beta) of aluminum titanate $\left(\mathrm{Al}_{2} \mathrm{O}_{3}\right.$. TiO $\left.\mathrm{TiO}_{2}-56.1 \% \quad \mathrm{Al}_{2} \mathrm{O}_{3}\right)$; the alpha form is stable from the alpha-beta inversion temperature of $1,820^{\circ} \pm 10^{\circ} \mathrm{C}$ and melts congruently at $1,860^{\circ} \pm 10^{\circ} \mathrm{C}$, and the beta form seems to be stable for periods up to 100 hours from room temperature to about $750^{\circ} \mathrm{C}$ and from about $1,300^{\circ} \mathrm{C}$ to its inversion temperature. The equilibria for the system $\mathrm{BeO}-\mathrm{Al}_{2} \mathrm{O}_{3}-\mathrm{TiO}_{2}$ was found to contain four invarient points: (1) at $1,572^{\circ} \pm 5^{\circ} \mathrm{C}$ and about mole ratio $2 \mathrm{BeO}: 1 \mathrm{Al}_{2} \mathrm{O}_{3}: 2 \mathrm{TiO}_{2}\left(16.1 \% \mathrm{BeO}, 32.7 \% \mathrm{Al}_{2} \mathrm{O}_{3}, 51.2 \% \mathrm{TiO}_{2}\right) ;(2)$ at $1,577^{\circ} \pm 5^{\circ} \mathrm{C}$ and about mole ratio $2 \mathrm{BeO}: 1 \mathrm{Al}_{2} \mathrm{O}_{3}: 4 \mathrm{TiO}_{2}\left(10.6 \% \mathrm{BeO}, 21.6 \% \mathrm{Al}_{2} \mathrm{O}_{3}, 67.8 \%\right.$ $\left.\mathrm{TiO}_{2}\right) ;(3)$ at $1,580^{\circ} \pm 5^{\circ} \mathrm{C}$ and about mole ratio $1 \mathrm{BeO}: 1 \mathrm{Al}_{2} \mathrm{O}_{3}: 1 \mathrm{TiO}_{2}\left(12.1 \% \mathrm{BeO}^{\circ} 49.3 \%\right.$ $\mathrm{Al}_{2} \mathrm{O}_{3}, 38.6 \% \mathrm{TiO}_{2}$ ) ; and (4) probably at about $1,755^{\circ} \pm 10^{\circ} \mathrm{C}$ and about mole ratio $2 \mathrm{BeO}: 5 \mathrm{Al}_{2} \mathrm{O}_{3}: 2 \mathrm{TiO}_{2}\left(7.0 \% \mathrm{BeO}, 79.8 \% \quad \mathrm{Al}_{2} \mathrm{O}_{3}, 22.2 \% \quad \mathrm{TiO}_{2}\right)$. No ternary compounds were found in this system.

The general physical properties of practically impervious porcelains of this system were found to be: maturing range, usually $1,525^{\circ}$ to $1,575^{\circ} \mathrm{C}$, but with some of the highalumina-containing bodies maturing between $1,600^{\circ}$ and $1,700^{\circ} \mathrm{C}$; apparent density, 3.3 to $3.7 \mathrm{~g} / \mathrm{cm}^{3}$; shrinkage, 11 to 19 percent; room-temperature compressive strength, 187,000 to $280,000 \mathrm{lb} /$ in. $^{2}$; room-temperature transverse strength, 13,700 to $25,000 \mathrm{lb} / \mathrm{in.}^{2}$; Young's modulus at room temperature, $42,000,000$ to $47,000,000 \mathrm{lb} /$ in $^{2}$; transverse strength at $1,800^{\circ}$ $\mathrm{F}\left(982^{\circ} \mathrm{C}\right), 10,500$ to $17,000 \mathrm{lb} /$ in. $^{2}$; approximate Young's modulus at $1,800^{\circ} \mathrm{F}, 22,000,000$ to $41,000,000 \mathrm{lb} /$ in. $^{2}$; relative thermal-shock resistance, poor; and the linear thermal expansion of a few selected bodies, in the range $25^{\circ}$ to $950^{\circ} \mathrm{C}$, usually was regular and ranged from 0.81 to 0.89 percent.
\end{abstract}

\section{Introduction}

The choice of the maximum gas or flame temperature in a gas-turbine or jet-propulsion engine is always a compromise between the demands of the designer and the characteristics of the available materials. Ceramic oxide porcelains offer materials of improved strength at temperatures above $1,800^{\circ} \mathrm{F}$, as compared to metallic alloys, but the inherently low relative resistance to thermal shock is a serious deterrent to their use. Consequently, the development of pure-oxide porcelains having both high strength and low thermal expansion should prove of considerable interest to design engineers.

Recently, attention has been devoted to the compound aluminum titanate $\left(\mathrm{Al}_{2} \mathrm{O}_{3}\right.$. TiO $\left.\mathrm{TiO}_{2}\right)$ because of its low linear thermal expansion (actually negative over a considerable temperature interval) in the range room temperature to about $1,000^{\circ} \mathrm{C}$. This study was undertaken in the hope that the low expansivity of this material could be combined with the high thermal conductivity of beryllium oxide to obtain a refractory porcelain that would exhibit high resist-

1 This project was sponsored by the Office of Naval Research under Contract Na ori 2-47, ONR Project NR 032-074. ance to thermal shock, high strength at elevated temperatures, low density, and that would be corrosion and erosion resistant.

Although such properties would be particularly applicable to turbine blades for an aircraft engine, it is important to realize that the use of oxide porcelains in future industrial units, such as a gas turbine for marine or land installation, may be of equal and possibly of greater importance. In addition, refractory porcelains are of interest to the manufacturers of spark plugs for automotive and aircraft reciprocating engines, to the refractory industry in general, and to the metallurgical industry.

\section{Materials, Equipment, and Procedures}

The equipment and procedures used in this study have already been described $[1$ to 4$] .^{2}$ In addition, a detailed discussion of the operation of the hightemperature thoria-resistor furnaces was published recently $\mid 5]$.

Materials of the highest obtainable purity were used for compounding the specimens for the deter-

${ }^{2}$ Figures in brackets indicate the literature references at the end of this paper 
mination of the phase relations in the various systems: beryllia $(\mathrm{BeO})$-fluorescent grade of over 99.9-percent purity; alumina $\left(\mathrm{Al}_{2} \mathrm{O}_{3}\right)$ - "alpha" polishing powder of nominal 99.9-percent purity supplied by the Linde Air Products Co.; and titania $\left(\mathrm{TiO}_{2}\right)_{-}$ spectroscopic grade of over 99.9-percent purity. Commercially available materials of high purity were used in the preparation of test specimens for the determination of physical properties: beryllialow calcined material of nominal 99.7-percent purity; alumina-ground, washed, and sieved material of 99.5-percent purity, supplied through the courtesy of the Champion Spark Plug Co.; and titania-TAM "Titanox A-MO", calcined at $1,100^{\circ} \mathrm{C}$. As prepared for use, the materials were, in all instances, sufficiently finely divided to pass the No. 325 U. S. Standard Sieve.

For the convenience of the reader, the test procedures employed are given briefly. Carbon tetrachloride was used for the absorption determinations, and the results were converted to equivalent waterabsorption values. Matured bodies were considered to be those having less than 0.1 percent of equivalent water absorption. Shrinkage values were calculated from micrometer measurements both before and after heating. Apparent density values were obtained by calculations based on the volume as determined by a mercury volumeter and the dry weight of the specimen. The ends of the specimens for the compressive-strength tests were ground parallel, so that the height-to-diameter ratio of the samples was approximately 2. The test pieces were placed between graphite-oil lubricated, cold-rolled steel blocks, and the compressive stress was applied at a rate of about $31,250\left(\mathrm{lb} / \mathrm{in}^{2}{ }^{2}\right) / \mathrm{min}$ by a $75,000-\mathrm{lb}$ hydraulic press. Ten cycles of quenching from a furnace at $1,700^{\circ} \mathrm{F}\left(931^{\circ} \mathrm{C}\right)$ to an air blast at room temperature constituted the thermal-shock test. Values for the transverse moduli of rupture and of elasticity were determined at room temperature, using the loading system of a transverse-strength test furnace [4]. Because of the poor thermal-shock resistance of beryllia-alumina-titania porcelains, comparable room-temperature transverse strengths after thermal shocking could not be determined. Young's modulus at room temperature was determined also by a sonic method [6]. The moduli of rupture and of elasticity at $1,800^{\circ} \mathrm{F}\left(982^{\circ} \mathrm{C}\right)$ were determined by loading the specimens in the transverse-strength test furnace [4] at 2-minute intervals in calculated stress increments of $1,500 \mathrm{lb} / \mathrm{in}^{2}$ When it was noted that the deflection following loading continued after the first minute, it was assumed that permanent deformation, or "plastic flow," had occurred. This deformation could be verified when the test pieces were examined for permanent curvature following rupture. In order to investigate the relative magnitude of the deformation, some of the test bars were subjected to a short-time stress-strain test at $1,800^{\circ}$ F. Beginning at $6,000-\mathrm{lb} /$ in. $^{2}$ stress, stress increments of $1,500 \mathrm{lb} / \mathrm{in} .^{2}$ were added to the bars at 1 -hour intervals, or until rupture occurred, during which time the deflection was measured at regular intervals.
Interferometric and dilatometric methods were used for the linear thermal expansion measurements.

The reported phase relations for the four systems investigated during this study were determined not only by interpreting the results obtained mainly from the melting-point and softening-range observations, but also from petrographic and X-ray examinations. The details of the melting-point and softening-range method are given in the publication devoted to the determination of the melting point of alumina [1] and in others [2, 3]. In addition, the three low-melting invariant-point temperatures for the system $\mathrm{BeO}-\mathrm{Al}_{2} \mathrm{O}_{3}-\mathrm{TiO}_{2}$ were redetermined, using a conventional type platinum-wound quenching furnace. The differences observed, using the two methods, are discussed in section 4.1.

The assignment of mole ratios to the various binary and ternary invariant points is not intended to indicate a belief that such invariant points correspond to definite mole ratios; hence, when an invariant point is described, it is said to be located "at about mole ratio . . ." The experimental work was done on the mole-ratio basis because if there is an unknown compound present, its composition will nearly always correspond to a simple molecular ratio, and, if sufficient simple mole-ratio mixtures are heated, the chances of missing the compound are minimized, regardless of the type of investigational procedure employed.

\section{Subordinate Binary Systems}

When this investigation was first undertaken, it was assumed that the equilibria of the three subordinate binary systems had been determined adequately. However, when it became necessary, because of inconsistant data, to redetermine the critical mixtures in each of the systems, it was found that the results of the present study did not agree in many respects with those given in the literature.

\subsection{The System Beryllia-Titania}

The equilibria in this system were described by Wartenburg, et al. [7] as including two congruently melting compounds, $3 \mathrm{BeO} . \mathrm{TiO}_{2}$ at about $1,800^{\circ} \mathrm{C}$ and $\mathrm{BeO}^{2} \mathrm{TiO}_{2}$ at about $1,720^{\circ} \mathrm{C}$. The results of the present investigation (fig. 1) indicate that the system contains no compounds, that a single eutectic exists at about 85 weight percent of $\mathrm{TiO}_{2}$ and $1,670^{\circ}$ $\pm 3^{\circ} \mathrm{C}$, and that a narrow region of $\mathrm{TiO}_{2}$ mixed crystals (an area of solid-solution) extends from just beyond the eutectic to pure titania. Early in the study, seven mixtures, ranging in composition from about 55 to 94 percent of $\mathrm{TiO}_{2}$, were specially heat-treated for X-ray diffraction examination. Each of the mixtures was heated to about 10 to 15 deg $\mathrm{C}$ above the melting point of the mixture as given by Wartenburg, cooled to the reported solidus temperatures, that temperature maintained for about 2 hours, and the mixture then cooled fairly rapidly (about $400 \mathrm{deg} \mathrm{C} / \mathrm{hr}$ to about $1,000^{\circ} \mathrm{C}$ ). 


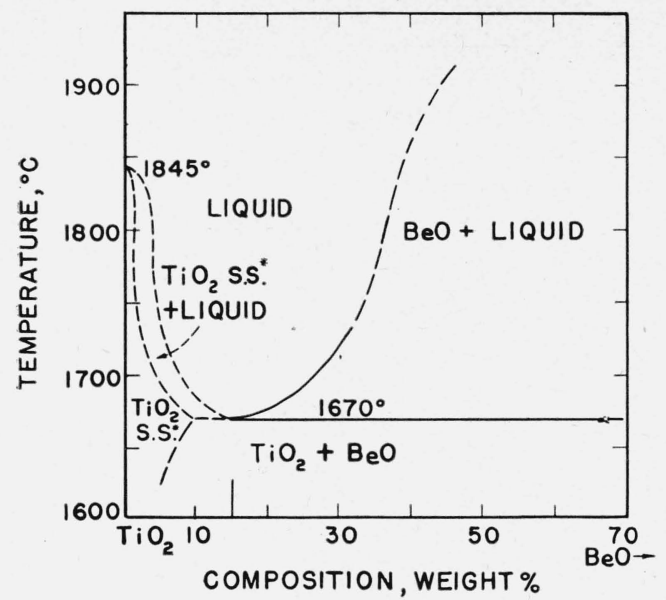

Figure 1. The system beryllia-titania. *Solid solution.

X-ray examination revealed that no compounds had been formed and that the specimens consisted entirely of bromellite $(\mathrm{BeO})$ and rutile $\left(\mathrm{TiO}_{2}\right)$.

Because the equipment was not available for high-temperature quenching studies, all the mixtures studied had to be cooled relatively slowly from the liquidus temperatures. As a result, neither petrographic nor X-ray examinations could substantiate the existence of the high-temperature solidsolution, and the results are necessarily based upon the observed melting behavior of the mixtures. All the observations of melting behavior of compositions in this system were made on specimens prepared from ground and repressed mixtures that had been calcined at $1,650^{\circ} \mathrm{C}$ for either 4 or $5 \mathrm{hrs}$. Table 1 gives the results of the petrographic and $\mathrm{X}$-ray examinations of some of the mixtures studied in the system $\mathrm{BeO}-\mathrm{TiO}_{2}$.

A limited study by the Pennsylvania State College [8] of some of the porcelains in this system indicated that no compounds were formed, and it was suggested that a solid-solution exists at higher temperatures.

\subsection{The System Beryllia-Alumina}

A considerable amount of work has been done on the system beryllia-alumina. In 1932 Wartenburg and Reusch [9] described this as a simple eutectic system. In 1946 Geller, et al. [2] crystallized and determined the congruent melting point of the compound chrysoberyl $\left(\mathrm{BeO} \cdot \mathrm{Al}_{2} \mathrm{O}_{3}\right)$. They suggested that the chrysoberyl could take at least 2 moles, but not 3 moles, of alumina into solid solution. Recently, Foster and Royal [10] in an investigation of alumina spark-plug bodies found that the compound $\mathrm{BeO}$.$3 \mathrm{Al}_{2} \mathrm{O}_{3}$ exists in the system. They did not determine the melting point of that compound, but, through a detailed discussion of previous work on the berylliaalumina system, they suggested the possible forms for the equilibrium diagram, pending determination of whether the compound $\mathrm{BeO} \cdot 3 \mathrm{Al}_{2} \mathrm{O}_{3}$ melted congruently or incongruently.

Figure 2 shows the equilibrium diagram of the system as redetermined for this study. Three eutectics were located: (1) at $1,890^{\circ} \pm 10^{\circ} \mathrm{C}$ and about mole ratio $1 \mathrm{BeO}: 4 \mathrm{Al}_{2} \mathrm{O}_{3}\left(94.2 \% \overline{\mathrm{Al}}_{2} \mathrm{O}_{3}\right) ;(2)$ at $1,850^{\circ} \pm 10^{\circ} \mathrm{C}$ and about mole ratio $2 \mathrm{BeO}: 3 \mathrm{Al}_{2} \mathrm{O}_{3}$ $\left(85.9 \% \mathrm{Al}_{2} \mathrm{O}_{3}\right)$; and (3) at $1,835^{\circ} \pm 10^{\circ} \mathrm{C}$ and about 75 weight percent of $\mathrm{Al}_{2} \mathrm{O}_{3}$. The melting point of the recently reported compound $\mathrm{BeO} .3 \mathrm{Al}_{2} \mathrm{O}_{3}(92.4 \%$ $\mathrm{Al}_{2} \mathrm{O}_{3}$ ) was found to be congruent at $1,910^{\circ} \pm 10^{\circ} \mathrm{C}$, and that of chrysoberyl $\left(\mathrm{BeO} \cdot \mathrm{Al}_{2} \mathrm{O}_{3}-80.3 \% \mathrm{Al}_{2} \mathrm{O}_{3}\right.$ ) was redetermined at $1,870^{\circ} \pm 10^{\circ} \mathrm{C}$. An interesting feature of the new compound, as pointed out by Foster and Royal, is that its optical properties are almost identical to those of chrysoberyl, and that the only reliable identification method is by X-ray examination. Table 2 gives the results of the petrographic and X-ray examinations of some of the compositions for this system. More than 95-per-

TABLE 1. Results of melting-point and softening-range observations and of petrographic and X-ray examinations of some mixtures in the system $\mathrm{BeO}-\mathrm{TiO}_{2}$

\begin{tabular}{|c|c|c|c|c|c|c|c|}
\hline \multicolumn{4}{|c|}{ Composition } & \multirow{2}{*}{$\begin{array}{l}\text { Maxi- } \\
\text { mum } \\
\text { tempera- } \\
\text { ture }\end{array}$} & \multirow{2}{*}{$\begin{array}{l}\text { Effect of heating a (all temperatures } \\
\left.\qquad \text { in }^{\circ} \mathrm{C}\right)\end{array}$} & \multirow{2}{*}{ Results of petrographic and X-ray examinations b } & \multirow{2}{*}{ Test } \\
\hline $\mathrm{BeO}$ & $\mathrm{TiO}_{2}$ & $\mathrm{BeO}$ & $\mathrm{TiO}_{2}$ & & & & \\
\hline Mole & Mole & $w t \%$ & $w t \%$ & ${ }^{\circ} \mathrm{C}$ & & & \\
\hline 4 & 1 & 55.61 & 44. 39 & 1,850 & $\begin{array}{l}\text { Fusion began at } 1,668^{\circ} \text {, not completed } \\
\text { at } 1,850^{\circ} \text {. }\end{array}$ & $\begin{array}{l}\text { Bromellite occurs as } 60-\mu \text { crystals in a matrix of } 40-\mu \\
\text { rutile. }\end{array}$ & 779 \\
\hline 3 & 1 & 48.44 & 51.56 & 1,801 & $\begin{array}{l}\text { Fusion began at } 1,672^{\circ} \text {, not eompleted } \\
\text { at } 1,801^{\circ} \text { (nor at } 1,850^{\circ} \text { for another } \\
\text { specimen). }\end{array}$ & $\begin{array}{l}\text { Similar to } 4 \mathrm{BeO}: \mathrm{TiO}_{2} \text {, but with somewhat larger } \\
\text { interstitial rutile crystals. X-ray: } \mathrm{BeO} \text { plus } \mathrm{TiO}_{2} \text {. }\end{array}$ & 708 \\
\hline 2 & 1 & 38.51 & 61.49 & 1,752 & $\begin{array}{l}\text { Fusion began at } 1,672^{\circ} \text {, almost com- } \\
\text { pleted at } 1,752^{\circ} \text {. }\end{array}$ & $\begin{array}{l}\text { Bromellite is blocky and the rutile is sponge-like with } \\
\text { small round and dendritic } \mathrm{BeO} \text { inclusions. X-ray: } \\
\mathrm{BeO} \text { plus } \mathrm{TiO}_{2} \text {. }\end{array}$ & 742 \\
\hline 1 & 1 & 23.85 & 76.15 & 1,688 & $\begin{array}{l}\text { Fusion began at } 1,668^{\circ} \text {, completed at } \\
1,688^{\circ} \text {. }\end{array}$ & $\begin{array}{l}\text { Beryllia occurs as rounded crystals somewhat smaller } \\
\text { than the rutile and also as dendritic inclusions in the } \\
\text { rutile. X-ray: } \mathrm{BeO} \text { plus } \mathrm{TjO}_{2} \text {. }\end{array}$ & 734 \\
\hline$-\ldots$ & -.... & 15.00 & 85.00 & 1,697 & $\begin{array}{l}\text { Fusion began at } 1,669^{\circ} \text {, completed at } \\
\text { less than } 1,697^{\circ} \text {. Rapid melting at } \\
1,674^{\circ} \text {. }\end{array}$ & $\begin{array}{l}\text { Large rutile grains with dendritic bromellite inclusions. } \\
\text { Single bromellite grains are rare. X-ray: BeO plus } \\
\mathrm{TiO}_{2} \text {. }\end{array}$ & 732 \\
\hline 1 & 4 & 7.26 & 92.74 & 1,698 & $\begin{array}{l}\text { Fusion began at } 1,680^{\circ} \text {, completed at } \\
\text { less than } 1,698^{\circ} \text {. }\end{array}$ & $\begin{array}{l}\text { Large }(100-\mu) \text { rutile and small bromellite. Dendritic } \\
\text { and round bromellite inclusions in rutile. X-ray: }\end{array}$ & 713 \\
\hline & & 4.00 & 96.00 & 1,749 & $\begin{array}{l}\text { Fusion began at } 1,687^{\circ} \text {, completed at } \\
1,749^{\circ} \text {. }\end{array}$ & Similar to $1 \mathrm{BeO}: 4 \mathrm{TiO}_{2}$, but with less bromellite....... & $792-\mathrm{N}$ \\
\hline
\end{tabular}

a In most cases, the beginning of fusion as indicated is for the test of the specimen described and is usually within $2^{\circ} \mathrm{C}$ of the average value obtained for three or more determinations of the same mixture. The term "complete fusion" or more determinations of the same mixture. The term "complete fusion"
means that the pyramidal specimen had fused sufficiently to flow into a flat button shape and does not necessarily connote that the mixture had completely liquefied.

b Specimens examined were not quenched, and the phases observed may not be those in equilibrium at the maximum temperature of hesting or at the liquidus. 


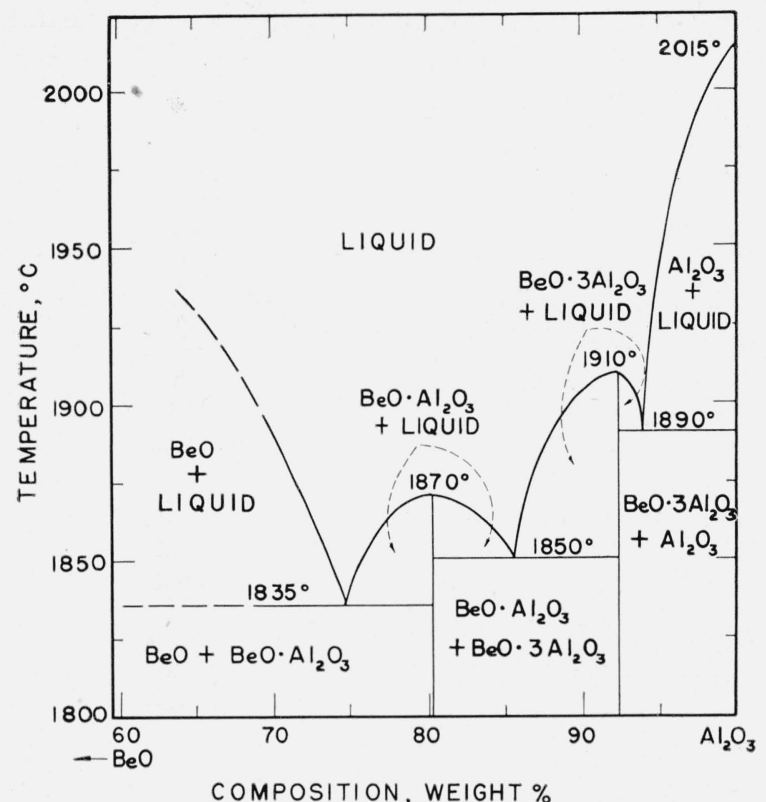

FiguRE 2. The system beryllia-alumina.

cent conversion to the compound chrysoberyl was found when equimolar mixtures of beryllia and alumina were heated at $1,250^{\circ} \mathrm{C}$ for $4 \mathrm{hrs}$.

In this system an unidentified phase of high index, $\eta=1.80$ to 1.81 , was found petrographically to be most pronounced, ranging up to an estimated 10 percent by volume, in those mixtures whose compositions ranged from chrysoberyl to alumina. Another unidentified phase, ranging up to an estimated 15 percent by volume, was found by X-ray examination in those mixtures whose compositions ranged from chrysoberyl to beryllia. The phase observed by X-rays was found to have a major $d$-spacings of $3.13,2.71$, and $1.916\left(\mathrm{CuK}_{\alpha 1}\right)$. In no instance was it possible to determine the presence of both unidentified phases in the same specimen and there was

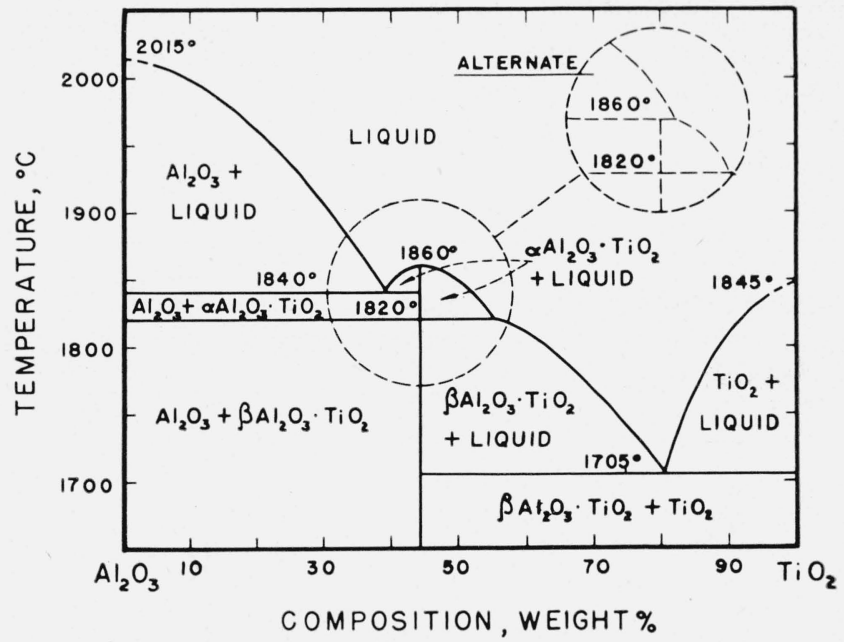

Figure 3. The system alumina-titania.

no indication that both phases were similar in any respect. In addition, it was not possible at any time to identify either phase in the same specimen by both petrographic and X-ray examinations. The amount of contamination in these specimens was shown by spectrographic analyses to be very small, not exceeding 0.05 percent, although previous experience [1] had shown that when alumina was melted in the thoria-resistor furnaces contamination of the melt by the furnace atmosphere resulted.

\subsection{The System Alumina-Titania}

\section{a. Phase Relations}

The reports of both Wartenburg [9] and Bunting [11] on this system indicated a eutectic at about 20 weight percent of alumina and about $1,710^{\circ} \mathrm{C}$, a congruently melting compound at about $1,860^{\circ} \mathrm{C}$ $\left(\mathrm{Al}_{2} \mathrm{O}_{3}\right.$. TiO $\mathrm{O}_{2}$-as determined by Bunting), and a eutectic at about 62 weight percent of alumina and about $1,850^{\circ} \mathrm{C}$. The results of this study, figure 3 , are

TABLE 2. Results of melting-point and softening-range observations and of petrographic and X-ray examinations of some mixtures in the system $\mathrm{BeO}-\mathrm{A}_{2} \mathrm{O}_{3}$

\begin{tabular}{|c|c|c|c|c|c|c|c|}
\hline \multicolumn{4}{|c|}{ Composition } & \multirow{2}{*}{$\begin{array}{c}\text { Maxi- } \\
\text { mum } \\
\text { tem- } \\
\text { perature }\end{array}$} & \multirow{2}{*}{$\begin{array}{l}\text { Effect of heating a } \\
\text { (all temperatures in }{ }^{\circ} \mathrm{C} \text { ) }\end{array}$} & \multirow{2}{*}{ Results of petrographic and X-ray examinations b } & \multirow{2}{*}{ Test } \\
\hline $\mathrm{BeO}$ & $\mathrm{Al}_{2} \mathrm{O}_{3}$ & $\mathrm{BeO}$ & $\mathrm{Al}_{2} \mathrm{O}_{3}$ & & & & \\
\hline Mole & Mole & $\begin{array}{l}w t \% \\
4.00\end{array}$ & $\begin{array}{l}w t \% \\
96.00\end{array}$ & $\begin{array}{l}{ }^{\circ} \mathrm{C} \\
1,900\end{array}$ & $\begin{array}{l}\text { Fusion began at } 1,895^{\circ} \text {, not completed } \\
\text { at } 1,900^{\circ} \text {. }\end{array}$ & $\begin{array}{l}\text { Corundum occurs as large polyhedral grains as the pri- } \\
\text { mary phase, with large matrix grains of } \mathrm{BeO} .3 \mathrm{Al}_{2} \mathrm{O}_{3} \text {. } \\
\text { X-ray: } 10 \text { to } 20 \% \mathrm{Al}_{2} \mathrm{O}_{3} ; \text { remainder } \mathrm{BeO} .3 \mathrm{Al}_{2} \mathrm{O}_{3} .\end{array}$ & $871-\mathrm{N}$ \\
\hline 1 & 4 & 5. 78 & 94.22 & 1,899 & $\begin{array}{l}\text { Fusion began at } 1,886^{\circ} \text {, completed at } \\
\text { less than } 1,899^{\circ} \text {. Rapid melting at } \\
1,895^{\circ} \text {. }\end{array}$ & $\begin{array}{l}\mathrm{BeO} .3 \mathrm{Al}_{2} \mathrm{O}_{3} \text { appears to be primary phase }-100-\mu \text { poly- } \\
\text { hedral grains. Small amount round corundum. } \\
\text { X-ray: } 5 \% \mathrm{Al}_{2} \mathrm{O}_{3} \text {, remainder } \mathrm{BeO} .3 \mathrm{Al}_{2} \mathrm{O}_{3} \text {. remaind }\end{array}$ & $867-\mathrm{N}$ \\
\hline 1 & 3 & 7. 56 & 92.44 & 1,915 & Fusion completed at less than $1,915^{\circ}$ & Practically all $\mathrm{BeO} .3 \mathrm{Al}_{2} \mathrm{O}_{3}$ as $200-\mu$ plates or flakes. & 879 \\
\hline 2 & 3 & 14. 06 & 85. 94 & 1,865 & $\begin{array}{l}\text { Fusion began at } 1,846^{\circ} \text {, completed at } \\
\text { less than } 1865^{\circ} \text {. Rapid melting at } \\
1,850^{\circ} \text {. }\end{array}$ & 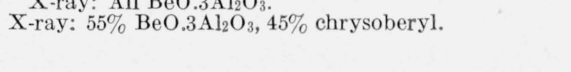 & $850-\mathrm{N}$ \\
\hline 1 & 1 & 19. 71 & 80.29 & 1,870 & $\begin{array}{l}\text { Fusion began at } 1,843^{\circ} \text {, rapid melting } \\
\text { at } 1,868^{\circ} \text {, completed fusion at } 1,870^{\circ} \text {. }\end{array}$ & $\begin{array}{l}\text { Chrysoberyl appears dirty from less than } 1-\mu \text { inclusions } \\
\text { and occurs as large plates or flakes. }\end{array}$ & 854 \\
\hline$\cdots$ & $-\cdots$ & 25. 00 & 75.00 & 1,860 & $\begin{array}{l}\text { Fusion began at } 1,837^{\circ} \text {, completed at } \\
\text { less than } 1,860^{\circ} \text {. }\end{array}$ & $\begin{array}{l}\text { Practically all chrysoberyl. Edges of crystals appear } \\
\text { cloudy, with } 5-\mu \text { intermixed beryllia. }\end{array}$ & $909-\mathrm{N}$ \\
\hline 2 & 1 & 32. 99 & 67.01 & 1,881 & $\begin{array}{l}\text { Fusion began at less than } 1,843^{\circ} \text {, not } \\
\text { completed at } 1,881^{\circ} \text {. }\end{array}$ & $\begin{array}{l}\text { Chrysoberyl appears cloudy, with inclusions of bromel- } \\
\text { lite. X-ray: } 75 \% \text { chrysoberyl and bromellite. }\end{array}$ & 862 \\
\hline
\end{tabular}

s In most cases, the beginning of fusion as indicated is for the test of the specimen described and is usually within $5^{\circ} \mathrm{C}$ of the average value obtained for three or more determinations of the same mixture. The term "complete fusion" means that the pyramidal specimen had fused sufficiently to flow into a flat button shape and does not necessarily connote that the mixture had completely liquefied. b Specimens examined were not quenched, and the phases observed may not be those in equilibrium at the maximum temperature of heating or at the liquidus. 
generally in close agreement with the results of those investigations. In addition, however, it was found that there are two forms of aluminum titanate.

Two eutectics were located at $1,705^{\circ} \pm 5^{\circ} \mathrm{C}$ and about 20 weight percent of $\mathrm{Al}_{2} \mathrm{O}_{3}$ and at $1,840^{\circ} \pm 10^{\circ}$ $\mathrm{C}$ and about mole ratio $5 \mathrm{Al}_{2} \mathrm{O}_{3}: 4 \mathrm{TiO}_{2}\left(61.5 \% \mathrm{Al}_{2} \mathrm{O}_{3}\right)$. The beta, or low-temperature, form of aluminum titanate $\left(\mathrm{Al}_{2} \mathrm{O}_{3} . \mathrm{TiO}_{2}, \quad 56.1 \% \quad \mathrm{Al}_{2} \mathrm{O}_{3}\right)$ seems to be stable for periods up to about $100 \mathrm{hr}$ in the range from room temperature to about $750^{\circ} \mathrm{C}$ and from about $1,300^{\circ}$ to its inversion temperature at about $1,820^{\circ} \mathrm{C}$. The alpha, or high-temperature, form is stable from $1,820^{\circ}$ to its meiting point at $1,860^{\circ} \pm 10^{\circ}$ C. It is realized that the equilibria proposed for the low-temperature stability of the beta form of the equimolar compound is not correct, but it was not considered of sufficient interest to devote considerable time and effort to completely investigate the kinetics of the problem. All the observations of melting behavior of compositions in this system were made on specimens prepared from ground and repressed mixtures that had been calcined at either $1,675^{\circ}$ or at $1,800^{\circ} \mathrm{C}$ for $2 \mathrm{hr}$. Table 3 gives the optical and $\mathrm{X}$-ray properties of the two forms of aluminum. titanate, and table 4 gives the results of the petrographic examinations of some of the mixtures of this system.

Because of the very viscous nature of the liquids formed when mixtures of alumina and titania were heated, especially for those containing more than 40 weight percent of alumina, considerable difficulty was experienced in interpreting the melting-point

TABLE 3. Optical and X-ray properties of alpha and beta aluminum titanate

\begin{tabular}{|c|c|c|c|c|c|c|}
\hline \multicolumn{3}{|c|}{ Optical properties } & \multicolumn{4}{|c|}{$\mathrm{X}$-ray diffraction patterns ( $\mathrm{CuK} \alpha_{1}$ radiation) } \\
\hline & \multirow{2}{*}{$\alpha \mathrm{Al}_{2} \mathrm{O}_{3} . \mathrm{TiO}_{2}$} & \multirow{2}{*}{$\beta \mathrm{Al}_{2} \mathrm{O}_{3} \cdot \mathrm{TiO}_{2}$} & \multicolumn{2}{|c|}{$\alpha \mathrm{Al}_{2} \mathrm{O}_{3} \cdot \mathrm{TiO}_{2}$} & \multicolumn{2}{|c|}{$\beta \mathrm{Al}_{2} \mathrm{O}_{3} \cdot \mathrm{TiO}_{2}$} \\
\hline & & & $d^{\mathrm{a}}$ & $i$ & $d^{\mathrm{b}}$ & $i$ \\
\hline 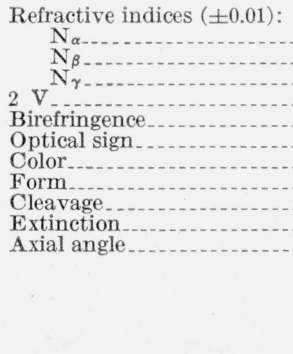 & 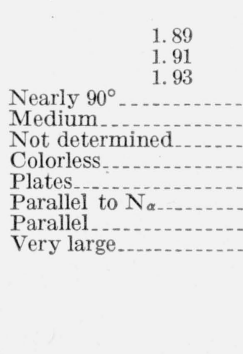 & $\begin{array}{ll} & \begin{array}{l}1.95 \\
\end{array} \\
& 1.97 \\
\text { Large } & 1.99 \\
\text { Medium } & \\
(-) & \\
\text { Blue pleochroism } \\
\text { Plates and needles } \\
\text { Parallel to } \mathrm{N}_{\alpha} \\
\text { Parallel } \\
\text { Very large }\end{array}$ & $\begin{array}{l}4.16 \\
3.76 \\
3.13 \\
2.836 \\
2.718 \\
2.601 \\
2.203 \\
1.871 \\
1.820 \\
1.718 \\
1.634 \\
1.563 \\
1.542 \\
1.466 \\
\end{array}$ & $\begin{array}{l}30 \\
15 \\
45 \\
23 \\
16 \\
100 \\
30 \\
36 \\
80 \\
18 \\
18 \\
18 \\
16 \\
21\end{array}$ & $\begin{array}{l}4.83 \\
4.73 \\
3.36 \\
2.657 \\
2.366 \\
2.146 \\
2.120 \\
1.902 \\
1.797 \\
1.786 \\
1.689 \\
1.607 \\
1.578 \\
1.489 \\
1.482 \\
1.251\end{array}$ & $\begin{array}{l}16 \\
45 \\
80 \\
100 \\
16 \\
42 \\
25 \\
75 \\
44 \\
17 \\
22 \\
22 \\
25 \\
25 \\
36 \\
12\end{array}$ \\
\hline
\end{tabular}

\& The strip-chart recording shows a total of 31 peaks for $\alpha \mathrm{Al}_{2} \mathrm{O}_{3}$. TiO $\mathrm{TiO}_{2}$, many of them were very weak (test 512 ).

b The strip-chart recording shows a total of 42 peaks for $\beta_{\mathrm{Al}_{2} \mathrm{O}_{3}}$. TiO $\mathrm{T}_{2}$, many of them were very weak (11-21-49).

TABLE 4. Results of melting-point and softening-range observations and of petrographic and X-ray examinations of some mixtures in the system $\mathrm{Al}_{2} \mathrm{O}_{3}-\mathrm{TiO}_{2}$

\begin{tabular}{|c|c|c|c|c|c|c|c|}
\hline \multicolumn{4}{|c|}{ Composition } & \multirow{2}{*}{$\begin{array}{l}\text { Maxi- } \\
\text { mum } \\
\text { temper- } \\
\text { ature }\end{array}$} & \multirow{2}{*}{$\begin{array}{l}\text { Effect of heating \& (all temperatures } \\
\qquad \text { in }^{\circ} \mathrm{C} \text { ) }\end{array}$} & \multirow{2}{*}{ Results of petrographic and X-ray examinations b } & \multirow{2}{*}{ Test } \\
\hline $\mathrm{Al}_{2} \mathrm{O}_{3}$ & $\mathrm{TiO}_{2}$ & $\mathrm{Al}_{2} \mathrm{O}_{3}$ & $\mathrm{TiO}_{2}$ & & & & \\
\hline $\begin{array}{c}\text { Mole } \\
2\end{array}$ & $\underset{1}{\text { Mole }}$ & $\begin{array}{l}w t \% \\
71.84\end{array}$ & $\begin{array}{l}w t \% \\
28.16\end{array}$ & ${ }^{\circ} C_{1}$ & $\begin{array}{l}\text { Fusion began at } 1,868^{\circ} \text {, not complete at } \\
1,880^{\circ} \text {. }\end{array}$ & $\begin{array}{l}\text { Corundum occurs as blocky crystals }(50 \%) \text {. About } \\
10 \% \alpha \mathrm{Al}_{2} \mathrm{O}_{3} \text {. TiO O Occurs as round or dendritic inclu- } \\
\text { sions in } \mathrm{BA}_{2} \mathrm{O}_{3} \text {. TiO }- \text { mav be an exsolution texture }\end{array}$ & $762-\mathrm{N}$ \\
\hline 5 & 4 & 61.46 & 38.54 & 1,850 & $\begin{array}{l}\text { Fusion began at } 1,826^{\circ} \text {, very rapid at } \\
1,837^{\circ} \text {, completed at less than } 1,850^{\circ} \text {. }\end{array}$ & $\begin{array}{l}\text { Practically all } \beta \mathrm{Al}_{2} \mathrm{O}_{3} . \mathrm{TiO}_{2} \text {, but with a small amount } \\
\text { of intermixed corundum and rutile as dendrites. }\end{array}$ & 728 \\
\hline 9 & 8 & 58. 76 & 41. 24 & 1,858 & $\begin{array}{l}\text { Fusion began at } 1,828^{\circ}, \text { rapid at } 1,840^{\circ}, \\
\text { completed at less than } 1,858^{\circ} .\end{array}$ & $\begin{array}{l}\text { Rutile and corundum only. Rutile in form of } \\
\text { grains, and dendrites appears interstitial to blocky }\end{array}$ & 727 \\
\hline 1 & 1 & 56.06 & 43.94 & 1,871 & $\begin{array}{l}\text { Fusion began at } 1,839^{\circ} \text {, completed at } \\
\text { less than } 1,870^{\circ} \text {. Crystallization at } \\
1,818^{\circ} \text {. }\end{array}$ & $\begin{array}{l}\text { Slowly heated and cooled specimen showed polyhedral } \\
\text { grains of } \mathrm{\beta Al}_{2} \mathrm{O}_{3} \text {. TiO } \mathrm{O}_{2} \text { and some corundum. }\end{array}$ & 802 \\
\hline 1 & 1 & 56.06 & 43. 94 & 1,839 & $\begin{array}{l}\text { Fusion began at } 1,808^{\circ} \text {, rapid at } 1,830^{\circ} \text {, } \\
\text { not complete at } 1,839^{\circ} \text {. }\end{array}$ & $\begin{array}{l}\text { Rapidly heated and cooled specimen showed varying } \\
\text { amounts of } \alpha \text { and } \mathrm{\beta Al}_{2} \mathrm{O}_{3} \text {. TiO } \mathrm{O}_{2} \text { in different portions of } \\
\text { the specimen. Alpha phase ordinarily } 100 \text { by } 200 \mu \text {, } \\
85 \% \text { of central portion. }\end{array}$ & 806 \\
\hline 4 & 5 & 50.57 & 49. 43 & 1,851 & $\begin{array}{l}\text { Fusion began at } 1,822^{\circ} \text {, completed at } \\
\text { less than } 1,851^{\circ} \text {. }\end{array}$ & $\begin{array}{l}\text { Very large plates of } \boldsymbol{\beta A l}_{2} \mathrm{O}_{3} \text {. } \mathrm{TiO}_{2}(400 \text { by } 1,000 \mu) \text { with } \\
\text { droplets of rutile on surfaces. }\end{array}$ & 735-LB \\
\hline 2 & 3 & 45.96 & 54.04 & 1,859 & $\begin{array}{l}\text { Fusion began at } 1,712^{\circ} \text {, completed at } \\
\text { less than } 1,859^{\circ} \text {. Crystallization at } \\
1,847^{\circ} \text {. }\end{array}$ & $\begin{array}{l}\text { Large needles of } \boldsymbol{\beta A l}_{2} \mathrm{O}_{3} \text {. TiO } \\
\text { terstitial rutile. }\end{array}$ & $751-\mathrm{N}$ \\
\hline 1 & 5 & 20.33 & 79.67 & 1,710 & $\begin{array}{l}\text { Rapid and complete fusion at less than } \\
1,710^{\circ} \text {. }\end{array}$ & $\begin{array}{l}\text { Intermixed rutile and } \beta_{\mathrm{Al}_{2} \mathrm{O}_{3} \cdot \mathrm{TiO}_{2} \text { as eutectic area }} \text { mosaic. }\end{array}$ & 738-LB \\
\hline
\end{tabular}

2 In most cases, the beginning of fusion as indicated is for the test of the specimen described and is usually within $5^{\circ} \mathrm{C}$ of the average value obtained for three or more determinations of the same mixture. The term "complete fusion" means that the pyramidal specimen had fused sufficiently to flow into a flat button shape and does not necessarily connote that the mixture had completely liquefied. b Specimens examined were not quenched, and the phases observed may not be those in equilibrium at the maximum temperature of heating or at the liquidus 
and softening-range data. The information gathered for the nonstable melting relations indicated another compound (at about $58 \%$ of alumina) in the system in addition to aluminum titanate (56.1\% of alumina). This new phase was later identified as being the hightemperature form (alpha) of the equimolar compound. The shifting of the maximum melting-point temperature around the 1:1 mixture toward alumina indicated an incongruent melting of aluminum titanate or a solid-solution of alumina in aluminum titanate. Eight mixtures in addition to the 1:1, containing between 50 and 65 weight percent of alumina, were prepared and their melting points and fusion ranges determined, using both conventional and rapidly heated and cooled furnace schedules. The results of these tests indicated (1) the existance of an eutectic at about mole ratio $5 \mathrm{Al}_{2} \mathrm{O}_{3}: 4 \mathrm{TiO}_{2},(2)$ the existance of the alpha form of aluminum titanate, and (3) the maximum liquidus temperature for the series of mixtures located very close to the 1:1 composition. Although these results seem to show that the $\mathrm{Al}_{2} \mathrm{O}_{3}: \mathrm{TiO}_{2}$ melts congruently, the possibilities of incongruent melting and of alumina-aluminum titanate solid-solution cannot be discarded entirely because of the extreme difficulty experienced in determining the high temperatures involved, especially with the viscous nature of the liquids formed at those temperatures.

In order to obtain the two forms of the aluminum titanate, it was necessary to heat the samples very rapidly in the range $600^{\circ}$ to $1,500^{\circ} \mathrm{C}$ (usually not over $1 \frac{1}{2} \mathrm{hr}$ ) and to cool at a rate of at least $800 \mathrm{deg} \mathrm{C} / \mathrm{hr}$ (actually cooled $400 \mathrm{deg} \mathrm{C}$ in the first $5 \mathrm{~min}$ ). Because of the poor thermal-shock resistance of the thoria muffle in the furnace, only a limited number of tests of this type were practicable. It was only by this means, however, that the alpha form could be partially "frozen" in the samples. Slow cooling permitted complete reversion of the alpha to the beta form in every instance, indicating that the reaction is reversible.

\section{b. The Compound Aluminum Titanate}

A communication from the Pennsylvania State College [12] gave the information that the linear thermal expansion of aluminum titanate in the range from room temperature to about $1,000^{\circ} \mathrm{C}$ was less than that of fused silica. Accordingly, the compound was formed, the linear thermal expansion was measured, and the result was found to agree. However, during a second determination of the expansivity, when the test temperature was raised to $1,500^{\circ} \mathrm{C}$, a very marked increase in the expansion rate for the material was found. An additional determination was made using the same specimen and heating it to the same maximum temperature. The high expansion rate was verified. During the correlation of these results, it was noted that the maximum negative expansion value and temperature during heating, the temperature at which the expansion became positive during heating, and the heating and cooling curves were markedly different for each test. Another test sample was prepared, and the expansiv-

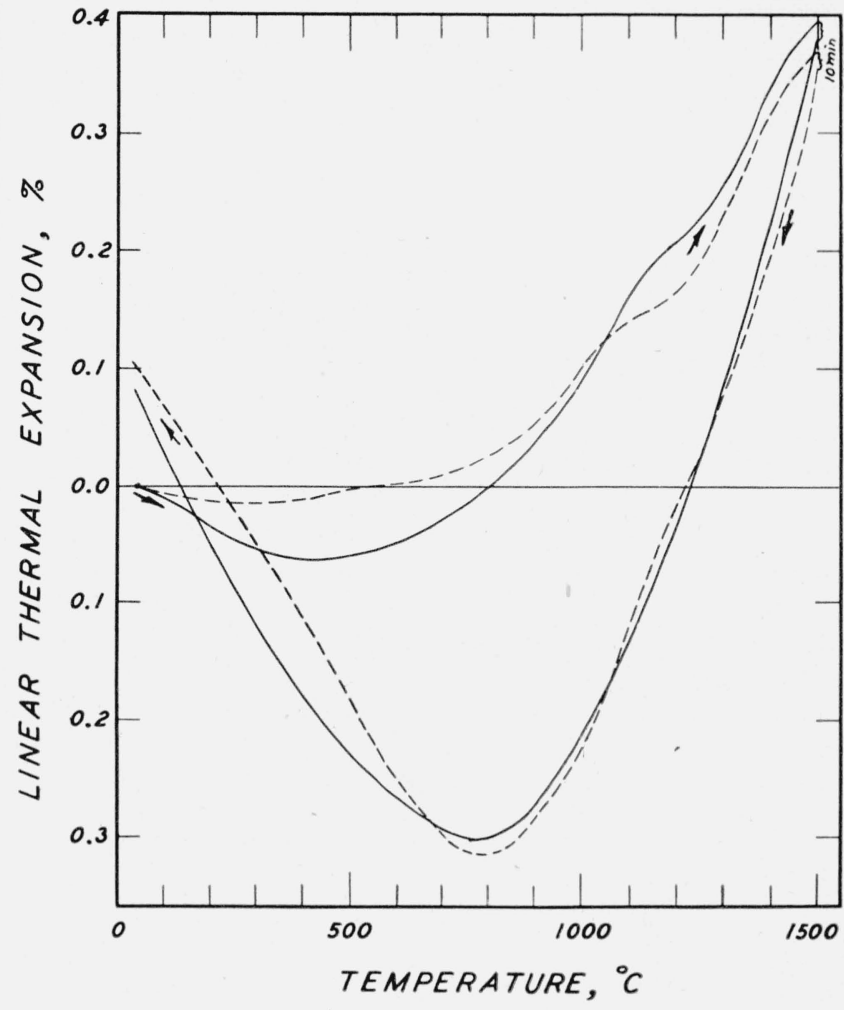

Figure 4. Linear thermal expansion of beta aluminum titanate.

Test specimen was prepared from equimolar proportions of the oxides, pressed at $9,400 \mathrm{lb} / \mathrm{in}^{2}$, and heated at $1,800^{\circ} \mathrm{C}$ for 1 hour before testing. 1st test curve $2 \mathrm{~d}$ test curve --- .

ity to $1,500^{\circ} \mathrm{C}$ was determined twice, using this same specimen. The results of these tests are shown in figure 4. A phase change was indicated in all the expansivity determinations for the compound by the change in slope of the heating curve between about $1,100^{\circ}$ and $1,300^{\circ} \mathrm{C}$, combined with the difference in the heating and cooling curves, and the growth of the specimen after each test. However, no transitions in the range $900^{\circ}$ to about $1,350^{\circ} \mathrm{C}$ were evident by differential thermal analyses.

An investigation of the possible dissociation of the compound was then undertaken. The relative amounts of the formation, decomposition, and reformation products of aluminum titanate were estimated in volume percentages by petrographic examination. Original crystallization was accomplished by heating equimolar mixtures of alumina and titania at temperatures of $1,600^{\circ}, 1,700^{\circ}$, and $1,800^{\circ} \mathrm{C}$ for $1 \mathrm{hr}$.

Three groups of raw materials of varying purities were used. Series A material was made from oxides of the highest purity obtainable (the same as those used for the phase-relation studies), series B material was made from commercially available, high-purity oxides (the same as those used for the determination of physical properties), and series C material was made from commercially available, high-purity alumina and spectroscopic grade titania. For each of the groups complete conver- 
sion to the compound resulted from the $1,800^{\circ} \mathrm{C}$ electric-furnace heat treatment. After the $1,700^{\circ} \mathrm{C}$ treatment, the $\mathrm{B}$ and $\mathrm{C}$ mixtures were completely converted, but the purest mixture was 98 percent converted. After the $1,600^{\circ} \mathrm{C}$ treatment the impure mixtures were 95 to 98 percent converted to the compound, and the A mixture was 90 percent converted. In addition, two trials at low temperature were carried out for the very pure, A, mixture; after $8 \mathrm{hr}$ at $1,350^{\circ} \mathrm{C}$, the material contained about 5 percent of aluminum titanate, but after $20 \mathrm{hr}$ at $1,300^{\circ} \mathrm{C}$ the specimen contained about 10 percent. When heated for $1 \mathrm{hr}$ at $1,700^{\circ} \mathrm{C}$ in a gas-fired furnace, about 95 percent of the highest purity mixture was converted to the compound. These results indicate that the higher the purity of the original materials, the more difficult is the formation of the compound at temperatures below $1,800^{\circ} \mathrm{C}$.

One sample of the A material, which had been heated at $1,800^{\circ} \mathrm{C}$ in an electric furnace, and one sample of the B material, which had been heated at $1,700^{\circ} \mathrm{C}$ in a gas-fired furnace, were reheated at $1,200^{\circ} \mathrm{C}$ for $25 \mathrm{hr}$. The result was that only about 2 percent of the compound remained in the A material, and only about 5 to 8 percent remained in the B material. This indicated that decomposition data would not only be necessary for the phase-equilibrium investigation, but would be equally important to the industrial fabricator using high-purity commercially available materials. Therefore, two bulk samples of series $\mathrm{A}$ and series B materials were prepared. Table 5 gives the results of the petrographic examinations of a number of these samples, which had received various heat treatments, for the study of the formation, decomposition, and re-formation characteristics of aluminum titanate.

From these and earlier results it was found: (1) that an area of instability exists for the compound in the temperature range from about $750^{\circ}$ to $1,300^{\circ} \mathrm{C}$, (2) that, generally, the purer the component oxides used for the formation treatment, the more easily the compound is decomposed, (3) that re-formation from the decomposed state seems to occur more readily for the pure material than for the originally less pure material, (4) that the effect of gas firing as the method of heat treatment increases the formation and reformation rates, regardless of the purity of the material, and (5) that it appears that two simultaneous processes, formation and decomposition, occur within a mixture of alumina and titania during the lower temperature treatments (about $1,100^{\circ}$ to $1,300^{\circ} \mathrm{C}$ ) with decomposition proceeding at a faster rate than formation after a time interval of something less than $25 \mathrm{hr}$.

A recent report by Hamelin [13] substantiates to a certain extent the upper limit of the aluminum titanate instability region reported in this paper. She found that heating equimolar mixtures of alumina and titania, with and without a 5-percent addition of boric oxide as a mineralizer, at $1,250^{\circ} \mathrm{C}$ for $1 / 2$ - and $1-h r$ periods resulted in no combination but that heating the same mixture for $10 \mathrm{~min}$ at $1,450^{\circ} \mathrm{C}$ resulted in complete conversion to the compound.

In addition, limited investigation of the properties of aluminum titanate bodies prepared both from raw and prereacted materials revealed that (a) pure alu-

TABLE 5. Effects of various heat-treatments on the compound aluminum titanate

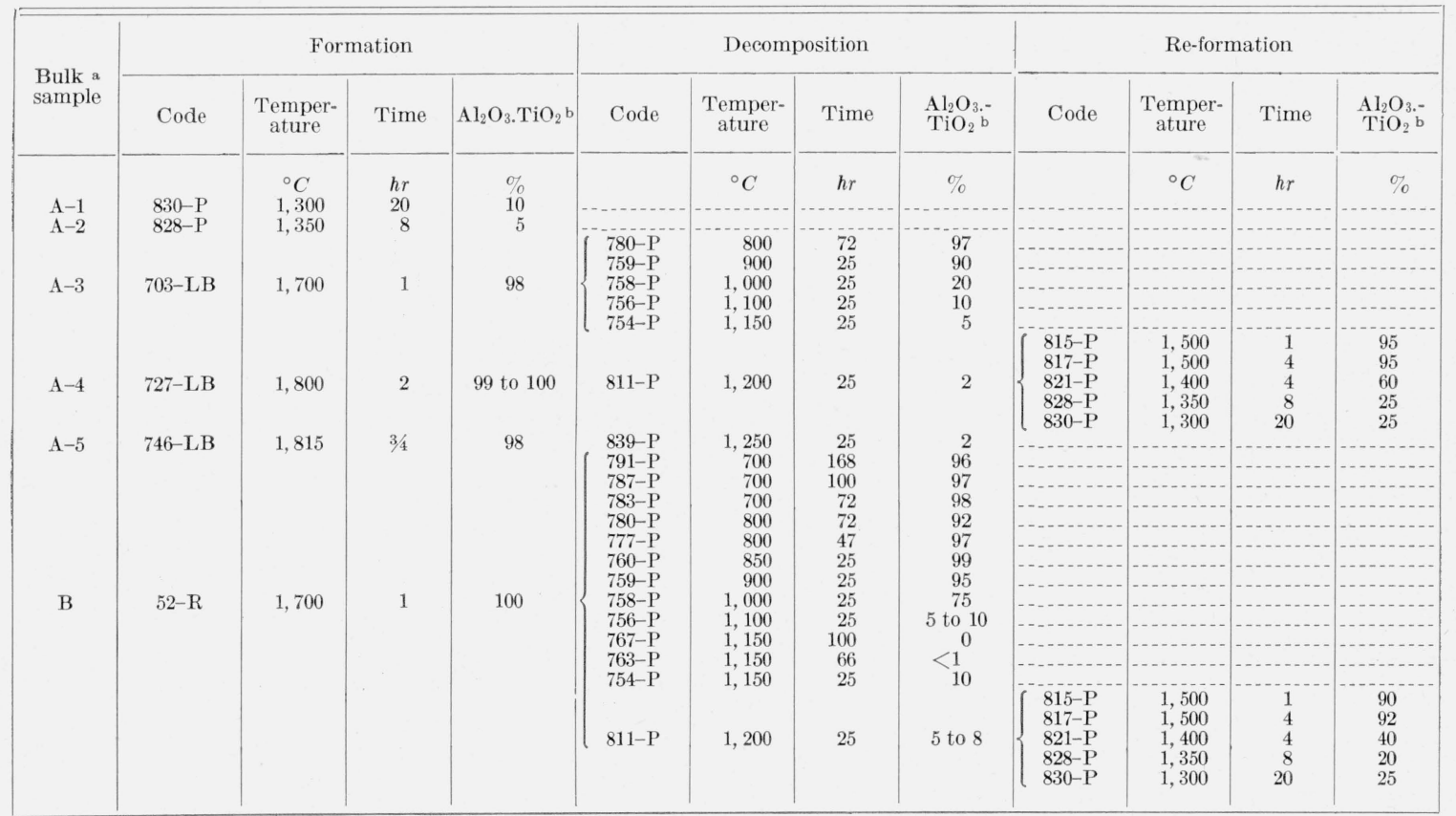

a All of the "A" series were made from oxides of the highest purity obtainable b Volume percentages of aluminum titanate estimated petrographically. and were from the same batch. The "B" sample was made from high-purity, commercially available oxides. 
minum titanate specimens are extremely friable when formed from the component oxides, (b) shapes have somewhat greater strength when formed from prereacted material, (c) the strength at room temperature is poor for either formation procedure when compared to the strengths of normal oxide porcelains, and $(d)$ the linear thermal expansion is very low, but only in the range from room temperature to about $1,000^{\circ} \mathrm{C}$.

\subsection{Titanium Dioxide}

Although it was apparent that titanium dioxide did reduce in the $\mathrm{BeO}-\mathrm{TiO}_{2}$ system, and to a much lesser extent in the $\mathrm{Al}_{2} \mathrm{O}_{3}-\mathrm{TiO}_{2}$ and $\mathrm{BeO}-\mathrm{Al}_{2} \mathrm{O}_{3}-\mathrm{TiO}_{2}$ systems, the amount of reduction is considered as being in trace quantities because no evidence of reduction could be found by petrographic or X-ray analyses. The discoloration of the samples (to a dark blue-black in extreme cases) is evidence of the reduction of titania, but it is well known that very small amounts of $\mathrm{Ti}_{2} \mathrm{O}_{3}$ (less than $0.01 \%$ ) have extremely strong coloring effects. The discoloration was noticed only in those specimens that contained free titania. Otherwise the samples were white or very light tan.

\section{The System Beryllia-Alumina-Titania}

\subsection{Phase Relations}

A search of the literature revealed that there are no published reports of a systematic study of the equilibria in the system beryllia-alumina-titania. The results of this investigation are shown in figure 5 , in which the indicated equilibria are based on the assumed congruent melting of alpha aluminum titanate (sec. 3.3, a). The limitation of funds did not permit completion of this phase of the investigation.

The report of this project to the Office of Naval Research [14] listed the invariant points of the system as being at (1) $1,575^{\circ} \pm 5^{\circ} \mathrm{C}$ and mole ratio $1 \mathrm{BeO}: 1 \mathrm{Al}_{2} \mathrm{O}_{3}: 1 \mathrm{TiO}_{2}$, (2) $1,579^{\circ} \pm 5^{\circ} \mathrm{C}$ and mole ratio

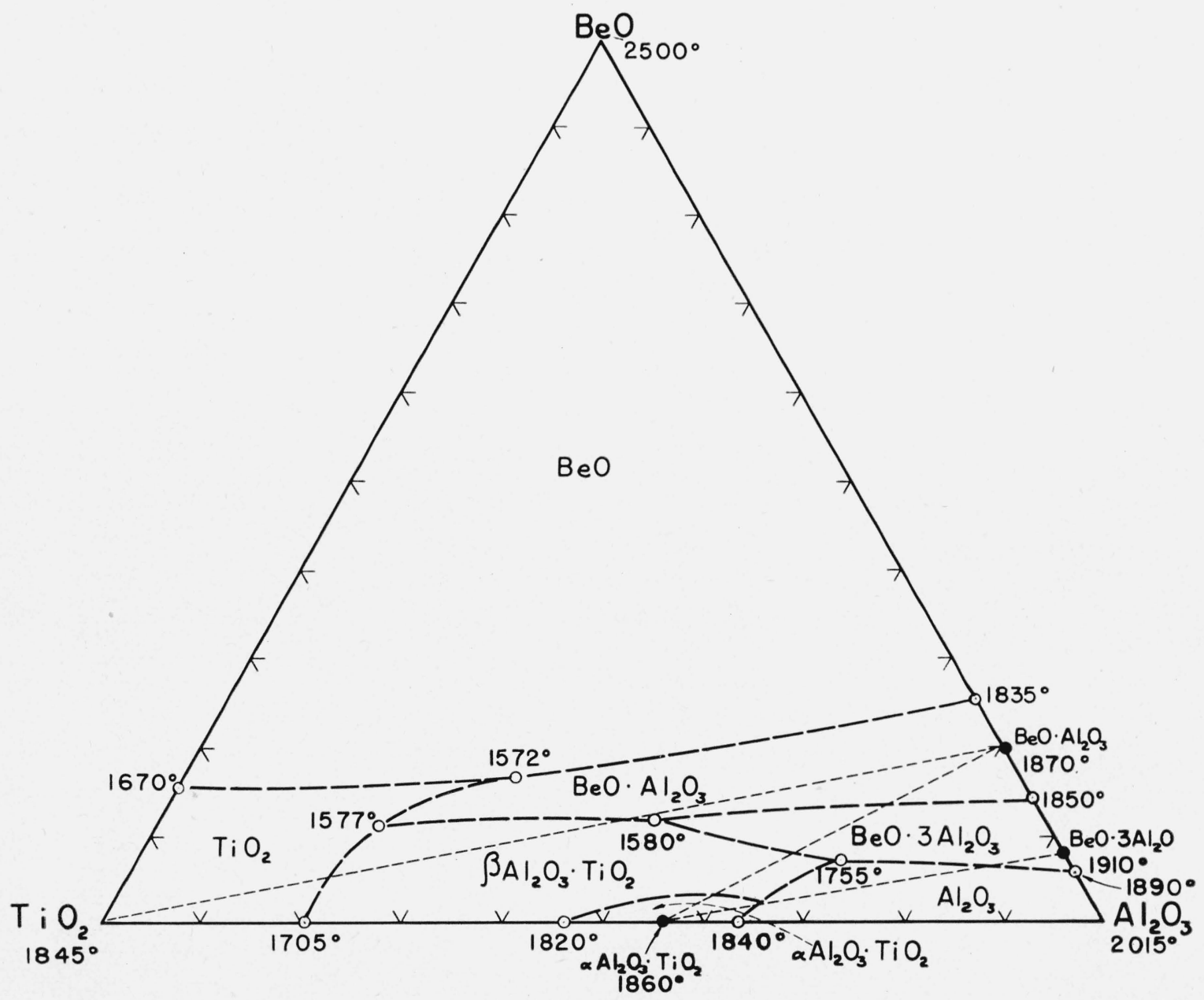

Figure 5. The system beryllia-alumina-titania.

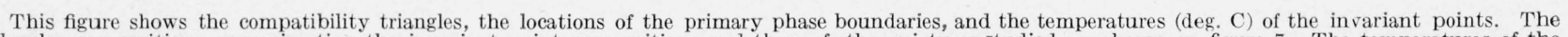

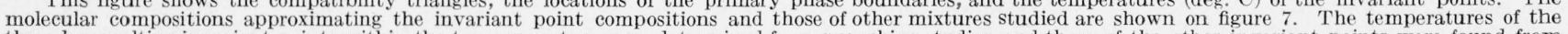

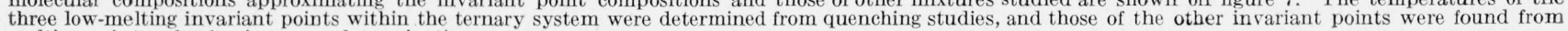
melting-point and softening-range determinations. 
$2 \mathrm{BeO}: 1 \mathrm{Al}_{2} \mathrm{O}_{3}: 2 \mathrm{TiO}_{2}$, (3) $1,586^{\circ} \pm 5^{\circ} \mathrm{C}$ and mole ratio $2 \mathrm{BeO}: 1 \mathrm{Al}_{2} \mathrm{O}_{3}: 4 \mathrm{TiO}_{2}$, and (4) probably at about $1,755^{\circ} \pm 10^{\circ} \mathrm{C}$ and about mole ratio $2 \mathrm{BeO}: 5 \mathrm{Al}_{2} \mathrm{O}_{3}$ : $2 \mathrm{TiO}_{2}$. No ternary compounds or areas of solid solution were positively identified. Results reported to ONR were obtained from melting-point and softening-range studies of compositions prepared from ground and repressed mixtures that had been calcined at about $1,570^{\circ} \mathrm{C}$ for $1 \mathrm{hr}$. Table 6 gives the results of petrographic examinations of some of the mixtures studied (see also fig. 6 for the locations of the mixtures on the ternary diagram).
Following the report to ONR and using a conventional type platinum-wound quenching furnace, a limited number of tests for a more accurate determination of the three low-melting invariant point temperatures were made. It was found that at mole ratio $1 \mathrm{BeO}: 1 \mathrm{Al}_{2} \mathrm{O}_{3}: 1 \mathrm{TiO}_{2}\left(12.1 \% \mathrm{BeO}, 49.3 \% \mathrm{Al}_{2} \mathrm{O}_{3}\right.$, $38.6 \% \mathrm{TiO}_{2}$ ) the solidus temperature was $1,580^{\circ}$ $\pm 5^{\circ} \mathrm{C}$, at mole ratio $2 \mathrm{BeO}: 1 \mathrm{Al}_{2} \mathrm{O}_{3}: 2 \mathrm{TiO}_{2}(16.1 \% \mathrm{BeO}$ $32.7 \% \mathrm{Al}_{2} \mathrm{O}_{3}, 51.2 \% \mathrm{TiO}_{2}$ ) it was $1,572^{\circ} \pm 5^{\circ} \mathrm{C}$, and at mole ratio $2 \mathrm{BeO}: 1 \mathrm{Al}_{2} \mathrm{O}_{3}: 4 \mathrm{TiO}_{2}(10.6 \% \mathrm{BeO}$, $21.6 \% \quad \mathrm{Al}_{2} \mathrm{O}_{3}, 67.8 \% \quad \mathrm{TiO}_{2}$ ) this temperature was $1,577^{\circ} \pm 5^{\circ} \mathrm{C}$.

TABLE 6. Results of melting-point and softening-range observations and of petrographic and X-ray examinations of some mixtures in the system $\mathrm{BeO}-\mathrm{Al}_{2} \mathrm{O}_{3}-\mathrm{TiO}_{2}$

\begin{tabular}{|c|c|c|c|c|c|c|c|c|c|}
\hline \multicolumn{6}{|c|}{ Composition } & \multirow{2}{*}{$\begin{array}{l}\text { Max- } \\
\text { imum } \\
\text { tempera- } \\
\text { ture }\end{array}$} & \multirow{2}{*}{$\begin{array}{l}\text { Effect of heating a (all } \\
\text { temperatures in }{ }^{\circ} \mathrm{C} \text { ) }\end{array}$} & \multirow{2}{*}{ Results of petrographic and X-ray examinations b } & \multirow{2}{*}{ Test } \\
\hline $\mathrm{BeO}$ & $\mathrm{Al}_{2} \mathrm{O}_{3}$ & $\mathrm{TiO}_{2}$ & $\mathrm{BeO}$ & $\mathrm{Al}_{2} \mathrm{O}_{3}$ & $\mathrm{TiO}_{2}$ & & & & \\
\hline $\begin{array}{c}\text { Mole } \\
\quad 1\end{array}$ & $\begin{array}{c}\text { Mole } \\
1\end{array}$ & $\begin{array}{c}\text { Mole } \\
1\end{array}$ & $\begin{array}{l}\text { wt } \% \\
12.095\end{array}$ & $\begin{array}{l}\text { wt } \% \\
49.275\end{array}$ & $\begin{array}{l}w t \% \\
38.63\end{array}$ & $\stackrel{\circ}{\circ}{ }_{1,594}^{-1}$ & $\begin{array}{l}\text { Fusion began at } 1,575^{\circ} \text {; } \\
\text { complete at less than } \\
1,594^{\circ} \cdot{ }^{\circ}\end{array}$ & $\begin{array}{l}\text { Eutectic texture: intermixed blocky, dendritic } \\
\text { bromellite }(10 \%) \text { and chrysoberyl or } \mathrm{BeO} .3 \mathrm{Al}_{2} \mathrm{O}_{3} \\
(40 \%) \text { and round, large rutile crystals }(50 \%) \text {. } \\
\text { Some rutile appears sponge-like, with uniden ti- } \\
\text { fied dendritic inclusions. X-ray (808-LB): Ru- } \\
\text { tile and chrysoberyl, possibly some BeO.c }\end{array}$ & $887-\mathrm{N}$ \\
\hline 1 & 1 & 3 & 6.83 & 27.80 & 65.37 & 1,614 & $\begin{array}{l}\text { Fusion began at } 1,601^{\circ} ; \\
\text { complete at less than } \\
1,614^{\circ} \text {. }\end{array}$ & $\begin{array}{l}\text { Dendritic structure of intermixed } \mathrm{BAl}_{2} \mathrm{O}_{3} . \mathrm{TiO}_{2} \\
\text { chrysoberyl, and rutile. Rutile about } 50 \% \text { by } \\
\text { volume. }\end{array}$ & $821-\mathrm{L}$ \\
\hline 1 & 2 & 1 & 8. 10 & 66.02 & 25.88 & 1,750 & $\begin{array}{l}\text { Fusion began at } 1,687^{\circ} \\
\text { almost complete at } \\
1,750^{\circ} \text {. }\end{array}$ & $\begin{array}{l}\text { About equal quantities of chrysoberyl or } \\
\mathrm{BeO} .3 \mathrm{Al}_{2} \mathrm{O}_{3} \text { and } \mathrm{A}_{2} \mathrm{O}_{3} \text {. TiO } \\
\text { dral grains, the aluminum titanate being } 30 \text { to } \\
150 \mu \text { in size. }\end{array}$ & $811-\mathrm{L}$ \\
\hline 1 & 2 & 2 & 6. 44 & 52.45 & 41.11 & 1,706 & $\begin{array}{l}\text { Fusion began at } 1,657^{\circ} \\
\text { almost complete at } \\
1,706^{\circ} \text {. }\end{array}$ & $\begin{array}{l}100-\mu \text { blocky } \mathrm{\beta Al}_{2} \mathrm{O}_{3} . \mathrm{TiO}_{2}(75 \%) \text { with polyhedral } \\
\text { chrysoberyl or } \mathrm{BeO} .3 \mathrm{Al}_{2} \mathrm{O}_{3} \text {. }\end{array}$ & 824-LB \\
\hline 1 & 3 & 1 & 6. 09 & 74.46 & 19.45 & 1,800 & $\begin{array}{l}\text { Fusion began at } 1,737^{\circ} \\
\text { almost complete at } \\
1,800^{\circ} \text {. }\end{array}$ & $\begin{array}{l}\text { Large plates of chrysoberyl or } \mathrm{BeO} .3 \mathrm{Al}_{2} \mathrm{O}_{3} \text {, scales } \\
\text { of } \beta \mathrm{Al}_{2} \mathrm{O}_{3} \text {. TiO } \mathrm{Ti}_{2} \text { on surfaces. } \mathrm{About} 10 \% \text { corun- } \\
\text { dum. X } \mathrm{X} \text {-ray }(811-\mathrm{L}): \mathrm{BeO} \cdot 3 \mathrm{Al}_{2} \mathrm{O}_{3} \text { and } \\
\beta \mathrm{Al}_{2} \mathrm{O}_{3} \text {. TiO }\end{array}$ & $813-\mathrm{L}$ \\
\hline 2 & 1 & 2 & 16. 05 & 32.70 & 51.25 & 1,589 & $\begin{array}{l}\text { Fusion began at } 1,579^{\circ} \text {; } \\
\text { complete at less than } \\
1,589^{\circ} \text {.c }\end{array}$ & $\begin{array}{l}\text { Intermixed, small crystals, bromellite, chryso- } \\
\text { beryl and rutile. }{ }^{c}\end{array}$ & 822-LB \\
\hline 2 & 1 & 4 & 10.61 & 21.61 & 67.77 & 1,592 & $\begin{array}{l}\text { Fusion began at } 1,588^{\circ} \text {; } \\
\text { complete at less than } \\
1,592^{\circ} \text {. }\end{array}$ & $\begin{array}{l}\text { Interinixed crystals of rutile }(30 \mu) \text { and chryso- } \\
\text { beryl. Very small, occasional grains of bromel- } \\
\text { lite. }{ }^{c}\end{array}$ & $817-\mathrm{L}$ \\
\hline 2 & 1 & 6 & 7.92 & 16.15 & 75.93 & 1,604 & $\begin{array}{l}\text { Fusion began at } 1,589^{\circ} \text {; } \\
\text { complete at less than } \\
1,604^{\circ} \text {. }\end{array}$ & $\begin{array}{l}\text { Practically all polyhedral rutile filled with inclu- } \\
\text { sions of unidentified material. Occasional } \\
\text { chrysoberyl. }\end{array}$ & $926-\mathrm{N}$ \\
\hline 2 & 1 & 10 & 5. 26 & 10.72 & 84.02 & 1,700 & $\begin{array}{l}\text { Fusion began at } 1,583^{\circ} \text {; } \\
\text { complete at less than } \\
1,700^{\circ} \text {. }\end{array}$ & $\begin{array}{l}\text { Same as } 2 \mathrm{BeO}: 1 \mathrm{Al}_{2} \mathrm{O}_{3}: 6 \mathrm{TiO}_{2}(926-\mathrm{N}) \text {, except more } \\
\text { rutile. }\end{array}$ & $812-\mathrm{LB}$ \\
\hline 3 & 3 & 1 & 16. 29 & 66.37 & 17.34 & 1,780 & $\begin{array}{l}\text { Fusion began at } 1,651^{\circ} \\
\text { almost complete at } \\
1,780^{\circ} \text {. }\end{array}$ & $\begin{array}{l}80 \%, 40-\mu \text {, polyhedral chrysoberyl or } \mathrm{BeO} .3 \mathrm{Al}_{2} \mathrm{O}_{3} \text {, } \\
\text { with small amount free rutile as interstitial ma- } \\
\text { terial. }\end{array}$ & 931 \\
\hline 3 & 5 & 1 & 11. 29 & 76.69 & 12.02 & 1,828 & $\begin{array}{l}\text { Fusion began at } 1755^{\circ} \\
\text { complete at } 1,828^{\circ} \text {. }\end{array}$ & $\begin{array}{l}\text { Practically all } 40 \text { to } 100 \mu \text { round crystals of chryso- } \\
\text { beryl or } \mathrm{BeO} .3 \mathrm{Al}_{2} \mathrm{O}_{3} \text {, with small, round inclu- } \\
\text { sions of possibly rutile. }\end{array}$ & $902-\mathrm{N}$ \\
\hline 3 & 10 & 1 & 6. 39 & 86. 805 & 6. 805 & 1,850 & $\begin{array}{l}\text { Fusion began at } 1800^{\circ} \\
\text { complete at } 1,850^{\circ} \text {. }\end{array}$ & 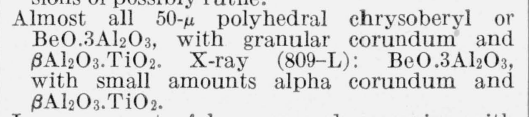 & $932-\mathrm{N}$ \\
\hline 3 & 20 & 1 & 3.42 & 92.94 & 3.64 & 1,800 & $\begin{array}{l}\text { No evidence of fusion at } \\
1,800^{\circ} \text {. }\end{array}$ & $\begin{array}{l}\text { Large amount of large corundum grains with } \\
\text { chrysoberyl or } \mathrm{BeO} .3 \mathrm{Al}_{2} \mathrm{O}_{3} \text { and trace of } \\
\mathrm{\beta Al}_{2} \mathrm{O}_{3} \text {. TiO } 2 \text {. X-ray }(809-\mathrm{L}): \mathrm{BeO} .3 \mathrm{Al}_{2} \mathrm{O}_{3} \text { and } \\
\alpha \mathrm{Al}_{2} \mathrm{O}_{3} \text {. }\end{array}$ & $809-\mathrm{L}$ \\
\hline 4 & 3 & 4 & 13.80 & 42.15 & 44.05 & 1,650 & $\begin{array}{l}\text { Fusion began at less than } \\
1,591^{\circ} ; \text { complete at less } \\
\text { than } 1,650^{\circ} \text {. }\end{array}$ & $\begin{array}{l}\text { Blocky chrysoberyl or } \mathrm{BeO} .3 \mathrm{Al}_{2} \mathrm{O}_{3} \text {, with rutile } \\
\text { and small amounts of bromellite. X-ray: } \\
\text { chrysoberyl, rutile, and trace of bromellite. }\end{array}$ & 804-LB \\
\hline 6 & 1 & 10 & 14. 28 & 9. 70 & 76.02 & 1,650 & $\begin{array}{l}\text { Fusion began at } 1,592^{\circ} \\
\text { complete at } 1,650^{\circ}\end{array}$ & $\begin{array}{l}\text { Rutile with interstitial dendritic bromellite and } \\
\text { Small amount of chrysoberyl or } \mathrm{BeO}_{3} \mathrm{Al}_{2} \mathrm{O}_{3} \text {. } \\
\text { X-ray: Rutile, bromellite, and chrysoberyl. }\end{array}$ & $810-\mathrm{LB}$ \\
\hline 9 & 1 & 9 & 21. 53 & 9. 74 & 68.73 & 1,646 & $\begin{array}{l}\text { Fusion began at } 1,589^{\circ} \text {; } \\
\text { complete at less than } \\
1,646^{\circ} \text {. }\end{array}$ & $\begin{array}{l}\text { Blocky bromellite, with blocky and dendritic ru- } \\
\text { tile, some of the rutile being dend ritic inclusions. }\end{array}$ & 886 \\
\hline 15 & 10 & 1 & 25.45 & 69.13 & 5. 42 & 1,830 & $\begin{array}{l}\text { Fusion began at } 1,778^{\circ} \\
\text { complete at } 1,830^{\circ} \text {. }\end{array}$ & $\begin{array}{l}\text { Chrysoberyl or } \mathrm{BeO} .3 \mathrm{Al}_{2} \mathrm{O}_{3} \text {, with mixed intersti- } \\
\text { tial, dendritic bromellite, and rutile. }\end{array}$ & 934 \\
\hline 15 & 15 & 1 & 18. 91 & 76.06 & 4. 03 & 1,840 & $\begin{array}{l}\text { Fusion began at } 1,803^{\circ} \\
\text { complete at } 1,840^{\circ}\end{array}$ & $\begin{array}{l}\text { Large chrysoberyl or } \mathrm{BeO} .3 \mathrm{Al}_{2} \mathrm{O}_{3} \text { prisms, with un- } \\
\text { identified dark interstitial film. X-ray }(809-\mathrm{L}) \text { : } \\
\text { Chrysoberyl. }\end{array}$ & $935-\mathrm{N}$ \\
\hline
\end{tabular}

a In most cases, the beginning of fusion as indicated is for the test of the specimen described and is usually within $3^{\circ} \mathrm{C}$ of the average value obtained for three or more determinations of the same mixture. The term "complete fusion" means that the pyramidal specimen had fused sufficiently to flow into a flat button shape and does not necessarily connote that the mixture had completely liquefied.

$\mathrm{b}$ Specimens examined were not quenched, and the phases observed may not be those in equilibrium at the maximum temperature of heating or at the liquidus. c Results of quenching studies: $1: 1: 1$ - solidus temperature $=1,580^{\circ} \pm 5^{\circ} \mathrm{C}$, primary phase chrysoberyl; $2: 1: 2-$ solidus temperature $=1,572^{\circ} \pm 5^{\circ} \mathrm{C}$, primary rutile. 
In addition to obtaining information on the differences in results that can be expected between the two methods of determining liquidus and solidus temperatures, identification of the primary phases was more readily established when the specimens could be quenched rather cooled relatively slowly as in the oxide-resistor furnaces. It was found also that the $1: 1: 1$ and the $2: 1: 2$ mixtures were located within the chrysoberyl primary phase region, and that the $2: 1: 4$ mixture was located within the rutile field. The linear thermal expansion measurements (see sections 4.2 and 4.3) gave another indication that the $1: 1: 1$ mixture should be located within the chrysoberyl field. It is believed, however, that the true invariant point compositions are located within about 2 weight percent of the compositions of the mole ratios used to describe the invariant points.

\subsection{Ceramic Bodies}

Tables 7, 8, and 9 give the maturing data, the strength-test values, and the results of the stressstrain studies of various porcelains whose compositions represent that area of the triaxial diagram (fig. 6) in which bodies could be formed with an equivalent water absorption of less than 0.1 percent. Figure 7 shows the stress--strain relations of those bodies selected for transverse--strength testing at $1,800^{\circ} \mathrm{F}$. The only porcelain that showed no plastic deformation during the testing had the molecular composition $1 \mathrm{BeO}: 1 \mathrm{Al}_{2} \mathrm{O}_{3}: 1 \mathrm{TiO}_{2}$. Figure 8 shows the effect of $1 / 2,1$, and 4 mole additions of beryllium oxide on the linear thermal expansion of the composition $1 \mathrm{Al}_{2} \mathrm{O}_{3}: 1 \mathrm{TiO}_{2}$.

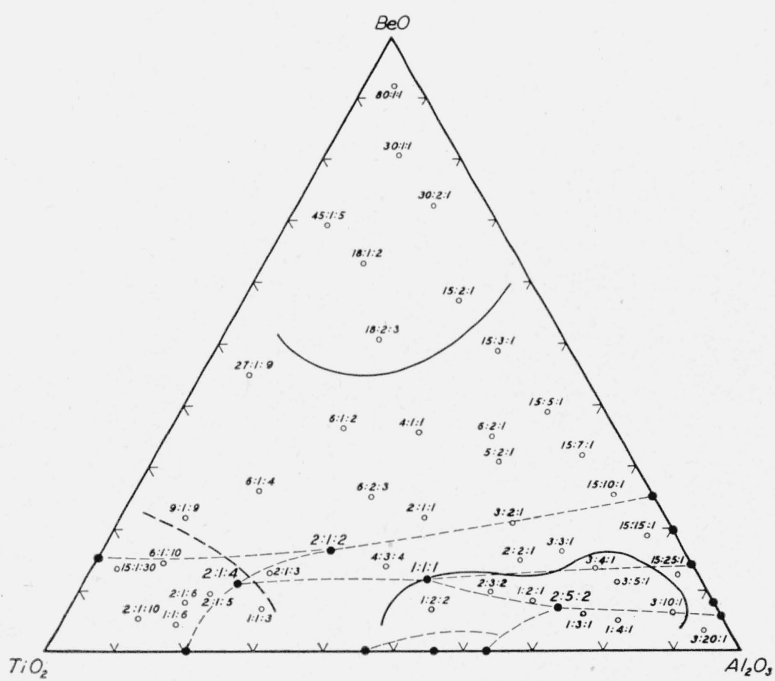

Figure 6. Porcelains of the system beryllia-alumina-titania.

This figure shows the location of the area in the triaxial diagram (the central portion) in which practically impervious porcelains may be made. Those com. positions between the upper heavy line and the $\mathrm{BeO}$-apex, and between the lower heavy line and the $\mathrm{Al}_{2} \mathrm{O}_{3}-\mathrm{TiO}_{2}$ boundary, could not be matured (less than $0.1 \%$ equivalent water absorption). The mixtures shown between the heavy dashed line and $\mathrm{TiO}_{2}$ were not used for physical property testing. The compositions of the mixtures are indicated on the figure in molar ratios but are placed graphically according to weight percentages.

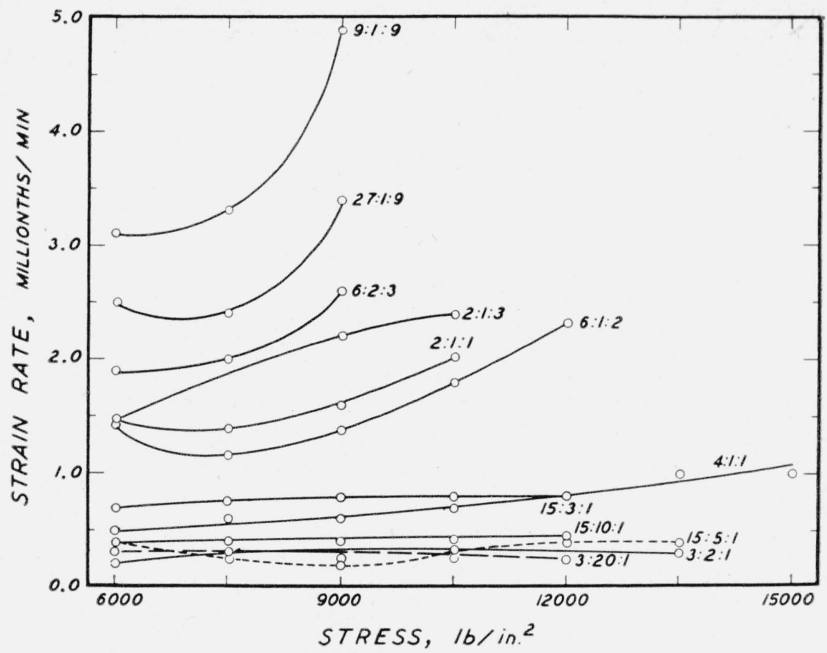

FIGURE 7. Short-time stress-strain relations of some berylliaalumina-titania procelains.

Shown are the strain rates at $1,800^{\circ} \mathrm{F}\left(982^{\circ} \mathrm{C}\right)$ of some beryllia-alumina-titania porcelains when maintained for 60 minutes at each of the stresses indicated. Rupture occurred during the next highest stress. (See values in table 9).

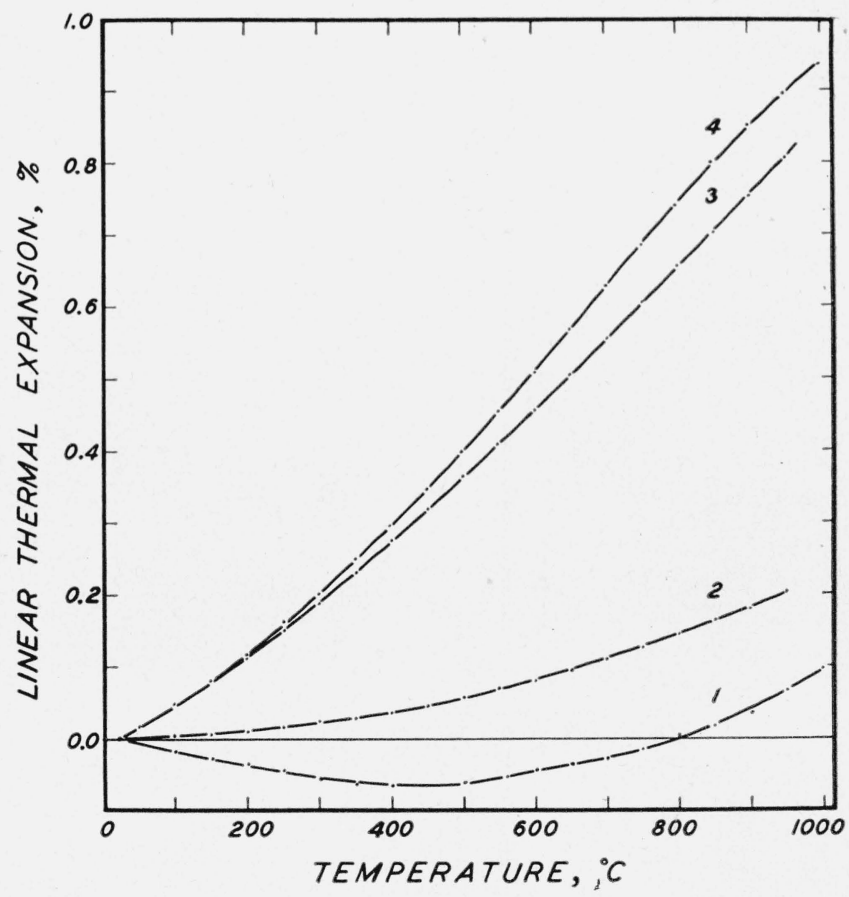

FiguRE 8. Linear thermal expansion of porcelains on the aluminum titanate-beryllia join.

These curves show the effect of $1 / 2,1$, and 4 mole additions of beryllia on the expansion of the aluminum titanate composition. The expansions of mole compositions $2 \mathrm{BeO}: 1 \mathrm{Al}_{2} \mathrm{O}_{3}: 3 \mathrm{TiO}_{2}, 6 \mathrm{BeO}: 1 \mathrm{Al}_{2} \mathrm{O}_{3}: 2 \mathrm{TiO}_{2}$, and $3 \mathrm{BeO}: 2 \mathrm{Al}_{2} \mathrm{O}_{3}: 1 \mathrm{TiO}$ compositions $2 \mathrm{BeO}: 1 \mathrm{Al}_{2} \mathrm{O}_{3}: 3 \mathrm{TiO}_{2}, 6 \mathrm{BeO}_{1} \mathrm{Al}_{2} \mathrm{O}_{3}: 2 \mathrm{TiO}_{2}$, and $3 \mathrm{BeO}_{2}: 2 \mathrm{Al}_{2} \mathrm{O}_{3}: 1 \mathrm{TiO}_{2}$
are similar to that of $1 \mathrm{BeO}: 1 \mathrm{Al}_{2} \mathrm{O}_{3}: 1 \mathrm{TiO}_{2}$. Curve 1 , $\mathrm{Al}_{2} \mathrm{O}_{3}: \mathrm{TiO}_{2} ;$ curve 2 ,

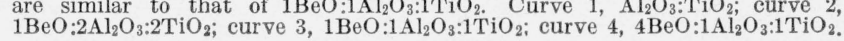


TABLE 7. Maturing-range studies and compressive-strength results of some $\mathrm{BeO}-\mathrm{Al}_{2} \mathrm{O}_{3}-\mathrm{TiO}_{2}$ porcelains *

\begin{tabular}{|c|c|c|c|c|c|c|c|c|c|c|c|c|c|c|c|c|c|c|}
\hline \multicolumn{6}{|c|}{ Molecular and weight-percentage compositions } & \multicolumn{6}{|c|}{ Results of maturing-range studies } & \multicolumn{7}{|c|}{ Properties of compressive-strength specimens b } \\
\hline \multirow[b]{2}{*}{$\mathrm{BeO}$} & \multirow[b]{2}{*}{$\mathrm{Al}_{2} \mathrm{O}_{3}$} & \multirow[b]{2}{*}{$\mathrm{TiO}_{2}$} & \multirow[b]{2}{*}{$\mathrm{BeO}$} & \multirow[b]{2}{*}{$\mathrm{A}_{2} \mathrm{O}_{3}$} & \multirow[b]{2}{*}{$\mathrm{TiO}_{2}$} & \multirow[b]{2}{*}{$\begin{array}{c}\text { Maturing } \\
\text { range }\end{array}$} & \multirow[b]{2}{*}{ Test } & \multicolumn{4}{|c|}{ Properties at maturity } & \multirow[b]{2}{*}{ Test } & \multirow[b]{2}{*}{$\begin{array}{l}\text { Tem- } \\
\text { pera- } \\
\text { ture }\end{array}$} & \multirow[b]{2}{*}{$\begin{array}{l}\text { Shrink- } \\
\text { age }\end{array}$} & \multirow[b]{2}{*}{$\begin{array}{c}\text { Absorp- } \\
\text { tion }\end{array}$} & \multirow[b]{2}{*}{$\begin{array}{l}\text { Appar- } \\
\text { ent o } \\
\text { density } \\
( \pm 0.01)\end{array}$} & \multirow[b]{2}{*}{$\begin{array}{c}\text { Height/ } \\
\text { diameter } \\
\text { ratio d }\end{array}$} & \multirow{2}{*}{$\begin{array}{l}\text { Strength } \\
\text { at room } \\
\text { tempera- } \\
\text { ture e } \\
( \pm 5,000 \\
\left.\text { lb/in. }{ }^{2}\right)\end{array}$} \\
\hline & & & & & & & & Temperature & $\begin{array}{c}\text { Shrink- } \\
\text { age }\end{array}$ & $\begin{array}{c}\text { Absorp- } \\
\text { tion }\end{array}$ & $\begin{array}{l}\text { Appar- } \\
\text { ent c } \\
\text { density } \\
( \pm 0.01)\end{array}$ & & & & & & & \\
\hline $\begin{array}{c}\text { Mole } \\
1 \\
2 \\
2 \\
2 \\
2\end{array}$ & $\begin{array}{c}\text { Mole } \\
1 \\
1 \\
1 \\
1 \\
2\end{array}$ & $\begin{array}{c}\text { Mole } \\
1 \\
1 \\
2 \\
3 \\
1\end{array}$ & $\begin{array}{l}\text { wt } \% \\
\text { 12. } 095 \\
21.58 \\
16.05 \\
12.775 \\
14.99\end{array}$ & $\begin{array}{l}w t \% \\
49.275 \\
43.96 \\
32.70 \\
26.025 \\
61.075\end{array}$ & $\begin{array}{l}\text { wt } \% \\
38.63 \\
34.46 \\
51.25 \\
61.20 \\
23.935\end{array}$ & $\begin{array}{l}{ }^{\circ} \mathrm{C} \\
1,575{ }^{1,525} \text { to } 1,575 \\
1,500 \text { to } 1,575 \\
1,525 \text { to } 1,575 \\
1,575 \text { to } 1,600\end{array}$ & $\begin{array}{l}679-\mathrm{L} \\
732-\mathrm{L} \\
-665-\mathrm{L} \\
730-\mathrm{L}\end{array}$ & $\begin{array}{l}1,575{ }^{\circ} \mathrm{C} \\
1,550 \\
1,525 \text { to } 1,550 \\
1,550 \\
1,575\end{array}$ & $\begin{array}{l}\% \\
15.82 \\
14.97 \\
16.32 \\
17.44 \\
13.06\end{array}$ & $\begin{array}{c}\% \\
0.02 \\
.00 \\
.00 \\
.01 \\
.01\end{array}$ & $\begin{array}{r}\mathrm{g} / \mathrm{cm}^{3} \\
3.67 \\
3.62 \\
3.64 \\
\text { 3. } 73 \\
\text { 3. } 59\end{array}$ & $\begin{array}{l}\text { 695-LB } \\
766-\mathrm{LB} \\
769 \mathrm{~L} \\
693-\mathrm{LB}\end{array}$ & $\begin{array}{l}{ }^{\circ} \mathrm{C} \\
1,575 \\
1,550 \\
1,525 \\
1,550\end{array}$ & $\begin{array}{l}\% \\
15.68 \\
16.72 \\
16.95 \\
17.60\end{array}$ & $\begin{array}{l}\% \\
0.01 \\
.01 \\
.02 \\
.00 \\
-.-.\end{array}$ & $\begin{array}{c}\mathrm{g} / \mathrm{cm}^{3} \\
3.66 \\
3.59 \\
3.66 \\
3.76\end{array}$ & $\begin{array}{l}2.09 \\
2.19 \\
2.13 \\
2.14\end{array}$ & $\begin{array}{l}\text { lb/in. }{ }^{2} \\
\text { f } 234 \times 10^{3} \\
\mathrm{f} 187 \\
226 \\
\mathrm{f} 237\end{array}$ \\
\hline $\begin{array}{l}3 \\
3 \\
3 \\
4 \\
4\end{array}$ & $\begin{array}{r}2 \\
3 \\
20 \\
20 \\
1 \\
3\end{array}$ & $\begin{array}{l}1 \\
1 \\
1 \\
1 \\
4\end{array}$ & $\begin{array}{r}20.92 \\
16.29 \\
3.42 \\
35.50 \\
13.80\end{array}$ & $\begin{array}{l}56.815 \\
66.37 \\
92.94 \\
36.16 \\
42.15\end{array}$ & $\begin{array}{l}22.265 \\
17.34 \\
3.64 \\
28.34 \\
44.05\end{array}$ & $\begin{array}{l}1,575 \\
1,575 \\
1,675 \text { to } 1,750 \\
1,550 \text { to } 1,575 \\
1,525 \text { to } 1,575\end{array}$ & $\begin{array}{l}679-\mathrm{L} \\
751-\mathrm{LB} \\
758-\mathrm{LB} \\
679-\mathrm{L} \\
732-\mathrm{L}\end{array}$ & $\begin{array}{l}1,575 \\
1,575 \\
1,725 \\
1,575 \\
1,550\end{array}$ & $\begin{array}{l}15.18 \\
12.42 \\
11.46 \\
16.93 \\
14.97\end{array}$ & $\begin{array}{l}.00 \\
.01 \\
.02 \\
.01 \\
.01\end{array}$ & $\begin{array}{l}\text { 3. } 52 \\
\text { 3. } 53 \\
\text { 3. } 64 \\
\text { 3. } 43 \\
\text { 3. } 73\end{array}$ & $\begin{array}{l}\text { 697-LB } \\
772-\mathrm{LB} \\
776-\mathrm{LB} \\
715-\mathrm{L} \\
768-\mathrm{LB}\end{array}$ & $\begin{array}{l}1,575 \\
1,575 \\
1,725 \\
1,575 \\
1,525\end{array}$ & $\begin{array}{l}15.87 \\
13.56 \\
12.34 \\
16.59 \\
15.78\end{array}$ & $\begin{array}{l}.01 \\
.01 \\
.01 \\
.01 \\
.03\end{array}$ & $\begin{array}{l}\text { 3. } 57 \\
3.50 \\
3.64 \\
3.36 \\
3.63\end{array}$ & $\begin{array}{l}2.09 \\
2.10 \\
\text { 1. } 98 \\
2.01 \\
2.12\end{array}$ & $\begin{array}{r}281 \\
\mathrm{f} 245 \\
\mathrm{~g} 240 \\
\mathrm{f} 263 \\
\mathrm{~g} 209\end{array}$ \\
\hline $\begin{array}{l}5 \\
6 \\
6 \\
6 \\
6\end{array}$ & $\begin{array}{l}2 \\
1 \\
1 \\
2 \\
2\end{array}$ & $\begin{array}{l}1 \\
2 \\
4 \\
1 \\
3\end{array}$ & $\begin{array}{l}30.60 \\
36.45 \\
26.26 \\
34.60 \\
25.285\end{array}$ & $\begin{array}{l}49.86 \\
24.75 \\
17.83 \\
46.99 \\
34.34\end{array}$ & $\begin{array}{l}\text { 19. } 54 \\
38.80 \\
55.91 \\
18.41 \\
40.375\end{array}$ & $\begin{array}{l}1,525 \text { to } 1,575 \\
1,550 \text { to } 1,575 \\
1,525 \text { to } 1,575 \\
1,525 \text { to } 1,575\end{array}$ & $\begin{array}{l}788-\mathrm{L} \\
665-\mathrm{L} \\
698-\mathrm{LB} \\
788-\mathrm{L} \\
691-\mathrm{L}\end{array}$ & $\begin{array}{l}1,550 \\
1,550 \\
1,525 \\
1,550 \\
1,550\end{array}$ & $\begin{array}{l}14.81 \\
17.60 \\
18.23 \\
14.65 \\
16.80\end{array}$ & $\begin{array}{l}.00 \\
.06 \\
.00 \\
.00 \\
.01\end{array}$ & $\begin{array}{r}3.41 \\
3.52 \\
-3.59\end{array}$ & $\begin{array}{l}699-\mathrm{LB} \\
770-\mathrm{LB} \\
771-\mathrm{L}\end{array}$ & $\begin{array}{l}1,550 \\
1,525 \\
11550\end{array}$ & $\begin{array}{l}17.91 \\
18.18 \\
16.97\end{array}$ & $\begin{array}{l}.00 \\
.01 \\
.02\end{array}$ & $\begin{array}{r}3.45 \\
3.57 \\
\end{array}$ & $\begin{array}{r}2.02 \\
2.19 \\
\end{array}$ & $\begin{array}{r}277 \\
+216 \\
-\ldots\end{array}$ \\
\hline & & & 25. 285 & 34.34 & 40.375 & 1,525 to 1,575 & $691-\mathrm{L}$ & 1,550 & 16.80 & .01 & 3. 59 & $771-\mathrm{L}$ & 1,550 & 16.97 & .02 & 3. 56 & 2. 12 & ${ }^{1} 247$ \\
\hline $\begin{array}{r}9 \\
15 \\
15 \\
15 \\
15\end{array}$ & $\begin{array}{r}1 \\
3 \\
5 \\
7 \\
10\end{array}$ & $\begin{array}{l}9 \\
1 \\
1 \\
1 \\
1\end{array}$ & $\begin{array}{l}21.53 \\
49.315 \\
38.895 \\
32.11 \\
25.45\end{array}$ & $\begin{array}{l}\quad 9.74 \\
40.185 \\
52.825 \\
61.05 \\
69.13\end{array}$ & $\begin{array}{r}68.73 \\
10.50 \\
8.28 \\
6.84 \\
5.42\end{array}$ & $\begin{array}{l}1,525 \text { to } 1,550 \\
1,550 \text { to } 1,575 \\
1,575 \text { to } 1,600 \\
1,525 \text { to } 1,575 \\
1,550 \text { to } 1,600\end{array}$ & $\begin{array}{l}665-\mathrm{L} \\
763-\mathrm{LB} \\
679-\mathrm{L} \\
763-\mathrm{LB} \\
751-\mathrm{LB}\end{array}$ & $\begin{array}{l}1,550 \\
1,550 \\
1,575 \\
1,550 \\
1,575\end{array}$ & $\begin{array}{l}18.71 \\
16.40 \\
15.82 \\
14.00 \\
12.73\end{array}$ & $\begin{array}{l}.01 \\
.01 \\
.01 \\
.01 \\
.01\end{array}$ & $\begin{array}{l}\text { 3. } 62 \\
3.27 \\
3.34 \\
3.41 \\
3.44\end{array}$ & $\begin{array}{l}701-\mathrm{LB} \\
767-\mathrm{L} \\
710-\mathrm{LB} \\
775-\mathrm{L} \\
764-\mathrm{LB}\end{array}$ & $\begin{array}{l}1,550 \\
1,550 \\
1,575 \\
1,550 \\
1,575\end{array}$ & $\begin{array}{l}\text { 18. } 86 \\
\text { 17. } 13 \\
\text { 15. } 58 \\
15.27 \\
14.58\end{array}$ & $\begin{array}{l}.00 \\
.02 \\
.00 \\
.05 \\
.00\end{array}$ & $\begin{array}{l}\text { 3. } 62 \\
\text { 3. } 26 \\
3.35 \\
3.39 \\
3.47\end{array}$ & $\begin{array}{l}\text { 1. } 97 \\
2.12 \\
1.91 \\
2.08 \\
2.07\end{array}$ & $\begin{array}{r}247 \\
239 \\
276 \\
\mathrm{~g} 237 \\
+247\end{array}$ \\
\hline $\begin{array}{l}15 \\
15 \\
27\end{array}$ & $\begin{array}{r}15 \\
25 \\
1\end{array}$ & $\begin{array}{l}1 \\
1 \\
9\end{array}$ & $\begin{array}{l}18.91 \\
12.50 \\
45.14\end{array}$ & $\begin{array}{r}77.06 \\
84.84 \\
6.81\end{array}$ & $\begin{array}{r}\text { 4. } 03 \\
2.66 \\
48.05\end{array}$ & $\begin{array}{l}1,600 \\
1,625 \text { to } 1,675 \\
1,550\end{array}$ & $\begin{array}{l}756-\mathrm{LB} \\
762-\mathrm{LB} \\
691-\mathrm{L}\end{array}$ & $\begin{array}{l}1,600 \\
1,650 \\
1,550\end{array}$ & $\begin{array}{l}11.14 \\
10.99 \\
18.86\end{array}$ & $\begin{array}{l}.01 \\
.01 \\
.01\end{array}$ & $\begin{array}{l}3.39 \\
3.49 \\
3.32\end{array}$ & $\begin{array}{l}778-\mathrm{LB} \\
773-\mathrm{L}^{-}\end{array}$ & $\begin{array}{l}1,625 \\
1,550\end{array}$ & $\begin{array}{r}12.03 \\
-18.28\end{array}$ & $\begin{array}{r}.01 \\
-.00\end{array}$ & $\begin{array}{r}3.37 \\
-3.32\end{array}$ & $\begin{array}{c}2.08 \\
2.18\end{array}$ & $\begin{array}{l}\mathrm{f} 236 \\
\mathrm{f} 206\end{array}$ \\
\hline
\end{tabular}

a Values obtained for specimens matured in a thoria-resistor (electric) furnace for $1 \mathrm{hr}$ at the temperatures specified.
$\mathrm{b}$ Unless otherwise indicated, the values given are the averages for three test specimens.
$\mathrm{c}$ Values calculated from the volume obtained from a mercury volumeter and c Values calculated from the volume obtained from a merc
the dry weight of the specimens.
d Specimens were about 1 in. high by $1 / 2$ in. in diameter. e Compression testing was done at a constant stress rate of 31,250 (1b/in.2)/ min and using cold-rolled-steel blocks for platen protection. i Value given is for two specimens (three were broken, but one had splintered,

g Value given is for one specimen (three were broken, but two had splintered, 
TABLE 8. Flexural strength, elasticity, and thermal-shock resistance of some $\mathrm{BeO}-\mathrm{Al}_{2} \mathrm{O}_{3}-\mathrm{TiO}_{2}$ porcelains a

\begin{tabular}{|c|c|c|c|c|c|c|c|c|c|c|c|}
\hline \multicolumn{3}{|c|}{ Moleb composition } & \multicolumn{4}{|c|}{ Maturing data ${ }^{\circ}$} & \multicolumn{5}{|c|}{ Strength in bending (flexure) at d- } \\
\hline \multirow{3}{*}{$\mathrm{BeO}$} & \multirow{3}{*}{$\mathrm{Al}_{2} \mathrm{O}_{3}$} & \multirow{3}{*}{$\mathrm{TiO}_{2}$} & \multirow{3}{*}{ Test } & \multirow{3}{*}{$\begin{array}{l}\text { Temper- } \\
\text { ature }\end{array}$} & \multirow{3}{*}{ Absorption } & \multirow{3}{*}{$\begin{array}{c}\text { Apparent } \\
\text { density } \\
( \pm .003)\end{array}$} & \multicolumn{3}{|c|}{ Room temperature } & \multicolumn{2}{|c|}{$1800^{\circ} \mathrm{F}\left(982^{\circ} \mathrm{C}\right)$} \\
\hline & & & & & & & \multirow{2}{*}{$\begin{array}{l}\text { Transverse } \\
\text { strength } \\
( \pm 2,000 \\
\left.1 \mathrm{~b} / \text { in. }{ }^{2}\right)\end{array}$} & \multicolumn{2}{|c|}{$\begin{array}{l}\text { Young's modulus } \\
\left( \pm 3 \times 10^{6} \mathrm{lb} \text {./in. }{ }^{2}\right)\end{array}$} & \multirow{2}{*}{$\begin{array}{c}\text { Transverse } \\
\text { strength } \\
( \pm 2,000 \\
\left.\text { lb/in. } .^{2}\right)\end{array}$} & \multirow{2}{*}{$\begin{array}{c}\text { Young's e } \\
\text { modulus } \\
\left( \pm 3 \times 10^{6}\right. \\
\text { lb/in. } \\
\text { (static) }\end{array}$} \\
\hline & & & & & & & & $\begin{array}{l}\text { Static f } \\
\text { method }\end{array}$ & $\begin{array}{l}\text { Sonic g } \\
\text { method }\end{array}$ & & \\
\hline $\begin{array}{l}1 \\
2 \\
2 \\
3 \\
3\end{array}$ & $\begin{array}{r}1 \\
1 \\
1 \\
2 \\
20\end{array}$ & $\begin{array}{l}1 \\
1 \\
3 \\
1 \\
1\end{array}$ & $\begin{array}{l}76-\mathrm{R} \\
77-\mathrm{R} \\
55-\mathrm{R} \\
56-\mathrm{R} \\
78-\mathrm{R}\end{array}$ & $\begin{array}{c}{ }^{\circ} \mathrm{C} \\
1,575 \\
1,550 \\
1,550 \\
1,575 \\
1,525\end{array}$ & $\begin{array}{r}\% \\
0.02 \\
1.15 \\
0.01 \\
\mathrm{ea} .15 \\
.00\end{array}$ & $\begin{array}{l}\mathrm{g} / \mathrm{cm}^{3} \\
3.62 \\
3.46 \\
3.72 \\
3.45 \\
3.58\end{array}$ & $\begin{array}{l}l b / i n .2^{2} \\
16.4 \times 10^{3} \\
16.8 \\
20.8 \\
20.5 \\
\text { h } 13.8\end{array}$ & \begin{tabular}{c}
$\begin{array}{c}l b / \mathrm{in} . .^{2} \\
41.8 \times 10^{6} \\
40.0\end{array}$ \\
\hdashline $\mathrm{n} 48.1$
\end{tabular} & 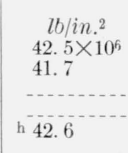 & $\begin{array}{l}\quad l b / \text { in. }^{2} \\
17.1 \times 10^{3} \\
12.2 \\
13.1 \\
13.5 \\
\mathrm{~h} 11.9\end{array}$ & $\begin{array}{l}\quad l b / \text { in }^{2}{ }^{2} \\
35.5 \times 10^{6} \\
30.5 \\
30.0 \\
35.1 \\
\text { ' } 39.0\end{array}$ \\
\hline $\begin{array}{r}4 \\
6 \\
6 \\
9 \\
15\end{array}$ & $\begin{array}{l}1 \\
1 \\
2 \\
1 \\
3\end{array}$ & $\begin{array}{l}1 \\
2 \\
3 \\
9 \\
1\end{array}$ & $\begin{array}{l}76-\mathrm{R} \\
55-\mathrm{R} \\
77-\mathrm{R} \\
55-\mathrm{R} \\
77-\mathrm{R}\end{array}$ & $\begin{array}{l}1,575 \\
1,550 \\
1,550 \\
1,550 \\
1,550\end{array}$ & $\begin{array}{r}.00 \\
.01 \\
.02 \\
.01 \\
1.7\end{array}$ & $\begin{array}{l}3.43 \\
3.44 \\
3.53 \\
3.64 \\
3.19\end{array}$ & $\begin{array}{l}20.1 \\
25.3 \\
21.8 \\
21.7 \\
19.7\end{array}$ & $\begin{array}{c}45.4 \\
42.1 \\
43.2\end{array}$ & $\begin{array}{l}46.8 \\
44.2 \\
43.5\end{array}$ & $\begin{array}{l}16.1 \\
14.6 \\
10.8 \\
11.0 \\
14.0\end{array}$ & $\begin{array}{l}35.8 \\
29.4 \\
27.7 \\
22.5 \\
34.8\end{array}$ \\
\hline $\begin{array}{l}15 \\
15 \\
27\end{array}$ & $\begin{array}{r}5 \\
10 \\
1\end{array}$ & $\begin{array}{l}1 \\
1 \\
9\end{array}$ & $\begin{array}{l}56-\mathrm{R} \\
76-\mathrm{R} \\
77-\mathrm{R}\end{array}$ & $\begin{array}{l}1,575 \\
1,575 \\
1,550\end{array}$ & $\begin{array}{r}0.02 \\
\text { ca.4 } \\
\text { ca. } 6\end{array}$ & $\begin{array}{l}\text { 3. } 35 \\
\text { 3. } 36 \\
3.33\end{array}$ & $\begin{array}{l}24.1 \\
17.5 \\
20.8\end{array}$ & $\begin{array}{l}43.3 \\
41.0\end{array}$ & $\begin{array}{l}44.1 \\
41.4\end{array}$ & $\begin{array}{l}16.0 \\
13.5 \\
11.9\end{array}$ & $\begin{array}{l}41.0 \\
36.3 \\
28.0\end{array}$ \\
\hline
\end{tabular}

a Values obtained for specimens matured in a gas-fired furnace for $1 \mathrm{hr}$ at the temperatures specified - The weight compositions of these molar ratio mixtures are given in tabie 7 .

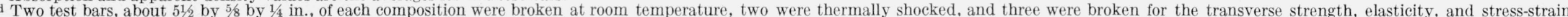

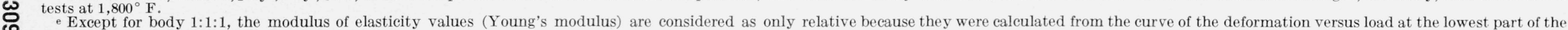
e Except for body 1:1:1, the modulus of elasticity values (Young's modulus) are considered as only relative because they w
curve where the plastic flow was a minimum.
f The static Young's modulus at room temperature was determined for only one bar specimen of the compositions indicated

$\mathrm{g}$ The static Young's modulus at room temperature was dermined for the two bars of the composition indicated, which were later used for the thermal shock test.

$\mathrm{h}$ Bars of this composition were tested in bending with a span of about $3 \frac{11}{2}$ in. as compared to the normal 4.9 - or 5.0 -in. span.

TABLE 9. Short-time (1 hour) stress-strain tests and interval strain rates of some $\mathrm{BeO}-\mathrm{Al}_{2} \mathrm{O}_{3}-\mathrm{TiO}_{2}$ porcelains

[All rates of strain are (in./in.)/min.]

\begin{tabular}{|c|c|c|c|c|c|c|c|c|c|c|c|c|c|c|c|c|c|c|c|}
\hline \multirow{2}{*}{\multicolumn{3}{|c|}{ Mole a composition }} & \multirow{2}{*}{\multicolumn{7}{|c|}{ Strain rates at $1,800^{\circ} \mathrm{F}\left(982^{\circ} \mathrm{C}\right) \mathrm{b}$ and- }} & \multicolumn{10}{|c|}{ Interval strain rates at $1,800^{\circ} \mathrm{F}$ and- } \\
\hline & & & & & & & & & & \multicolumn{5}{|c|}{$6,000 \mathrm{lb} / \mathrm{in} . ?$ stress for- } & \multicolumn{5}{|c|}{$12,000-\mathrm{lb} /$ in. $^{2}$ stress for- } \\
\hline $\mathrm{BeO}$ & $\mathrm{Al}_{2} \mathrm{O}_{3}$ & $\mathrm{TiO}_{2}$ & $\begin{array}{l}6,000- \\
\text { lb./in.2 } \\
\text { stress }\end{array}$ & $\begin{array}{l}7,500- \\
1 \text { b.//in. }{ }^{2} \\
\text { stress }\end{array}$ & $\begin{array}{l}9,000- \\
\mathrm{lb} / \mathrm{in} .^{2} \\
\text { stress }\end{array}$ & $\begin{array}{l}\text { 10,500- } \\
\text { lb/in. }{ }^{2} \\
\text { stress }\end{array}$ & $\begin{array}{l}\text { 12,000-- } \\
\text { lb/in. }{ }^{2} \\
\text { stress }\end{array}$ & $\begin{array}{l}13,500- \\
\text { lb/in. }{ }^{2} \\
\text { stress }\end{array}$ & $\begin{array}{l}\text { 15,000- } \\
\text { lb/in. }{ }^{2} \\
\text { stress }\end{array}$ & $\begin{array}{l}0 \text { to } 5 \\
\text { min }\end{array}$ & $\begin{array}{l}0 \text { to } 10 \\
\text { min }\end{array}$ & $\begin{array}{l}0 \text { to } 20 \\
\text { min }\end{array}$ & $\begin{array}{l}0 \text { to } 30 \\
\text { min }\end{array}$ & $\begin{array}{l}0 \text { to } 60 \\
\text { min }\end{array}$ & $\begin{array}{l}0 \text { to } 5 \\
\text { min }\end{array}$ & $\begin{array}{l}0 \text { to } 10 \\
\min \end{array}$ & $\begin{array}{l}0 \text { to } 20 \\
\text { min }\end{array}$ & $\begin{array}{l}0 \text { to } 30 \\
\text { min }\end{array}$ & $\begin{array}{c}0 \text { to } 60 \\
\text { min }\end{array}$ \\
\hline 2 & 1 & 1 & 1.5 & 1.4 & $\begin{array}{l}1.6 \\
2.2\end{array}$ & 2.1 & $(3.5)$ & ...... & ........ & 3.7 & 2. 9 & 2. 3 & 1. 9 & 1. 5 & 4.7 & 4. 2 & 3.5 & & $\cdots$ \\
\hline$\frac{2}{3}$ & $\begin{array}{l}1 \\
2\end{array}$ & $\begin{array}{l}3 \\
1\end{array}$ & $\begin{array}{l}1.6 \\
0.2\end{array}$ & 0.4 & $\begin{array}{l}2.2 \\
0.2\end{array}$ & $\begin{array}{l}2.4 \\
0.3\end{array}$ & $\begin{array}{c}(3.3) \\
0.2\end{array}$ & 0.3 & $(0.8)$ & $\begin{array}{l}3.4 \\
0.6\end{array}$ & $\begin{array}{l}3.0 \\
0.6\end{array}$ & $\begin{array}{l}2.3 \\
0.5\end{array}$ & $\begin{array}{l}2.0 \\
0.5\end{array}$ & $\begin{array}{l}1.6 \\
0.2\end{array}$ & $\begin{array}{l}4.5 \\
0.0\end{array}$ & $\begin{array}{l}4.0 \\
0.0\end{array}$ & $\begin{array}{l}3.3 \\
0.0\end{array}$ & 0.1 & 0.2 \\
\hline 3 & 20 & 1 & .3 & .3 & .2 & .2 & .2 & & & .7 & .6 & .5 & $\begin{array}{l}.4 \\
.4\end{array}$ & .3 & $\begin{array}{l}.0 \\
.4\end{array}$ & $\begin{array}{l}.0 \\
.2\end{array}$ & $\begin{array}{l}.0 \\
.3\end{array}$ & $\begin{array}{l}0.1 \\
.2\end{array}$ & $\begin{array}{l}0.2 \\
.2\end{array}$ \\
\hline 4 & 1 & 1 & .7 & .6 & .6 & .7 & .8 & 1.0 & 1.0 & 1.7 & 1.6 & 1.3 & 1.1 & .7 & 1.8 & 1. 6 & 1.4 & 1. 2 & .8 \\
\hline 6 & 1 & 2 & 1.4 & 1. 2 & & 1.8 & 2.3 & $(5.1)$ & -... & 4. 0 & 3. 2 & 2. 4 & 2. 0 & 1. 4 & 3.4 & 3.2 & 2. 9 & 2.7 & 2.3 \\
\hline $\begin{array}{l}6 \\
9\end{array}$ & $\begin{array}{l}2 \\
1\end{array}$ & $\begin{array}{l}3 \\
9\end{array}$ & $\begin{array}{l}1.9 \\
3.1\end{array}$ & $\begin{array}{l}2.0 \\
3.3\end{array}$ & $\begin{array}{l}2.6 \\
4.9\end{array}$ & $(4.2)$ & & & $\ldots .$. & $\begin{array}{l}4.1 \\
7.2\end{array}$ & $\begin{array}{l}3.6 \\
6.0\end{array}$ & $\begin{array}{l}2.9 \\
4.7\end{array}$ & $\begin{array}{l}2.6 \\
4.0\end{array}$ & $\begin{array}{l}1.9 \\
3.1\end{array}$ & $\ldots$ & & ..... & & ...... \\
\hline 15 & 3 & 1 & 0.7 & 0.6 & 0.8 & 0.7 & 0.8 & $(0.9)$ & ..... & 1. 5 & 1. 6 & 1. 2 & 1. 0 & 0.7 & 1.4 & 1.3 & 1.1 & 1.0 & 0.8 \\
\hline 15 & 5 & 1 & .4 & .3 & .2 & 4 & .4 & .4 & $\ldots$ & 2. 0 & 1.6 & 1.0 & 0.7 & .4 & 0.7 & 0.6 & 0.6 & 0.5 & .4 \\
\hline${ }_{27}^{15}$ & $\begin{array}{r}10 \\
1\end{array}$ & $\begin{array}{l}1 \\
9\end{array}$ & $\begin{array}{l}.3 \\
2,5\end{array}$ & 2.4 & $\begin{array}{r}.4 \\
3.4\end{array}$ & $(5.4)$ & .4 & $(1.0)$ & (n..... & $\begin{array}{l}0.8 \\
5.0\end{array}$ & $\begin{array}{l}0.7 \\
4.5\end{array}$ & $\begin{array}{l}0.6 \\
3.7\end{array}$ & $\begin{array}{r}.5 \\
3.0\end{array}$ & $\begin{aligned} .3 \\
2.5\end{aligned}$ & .6 & .6 & .5 & .5 & .4 \\
\hline & & & & & & & & & & & & & & & & & & & \\
\hline
\end{tabular}

The weight percentages of these molecular compositions, the maturing temperatures, and the properties of the matured porcelains are given in table 7.

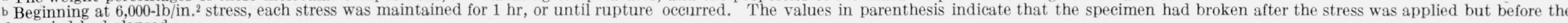
hourly period had elapsed. 


\subsection{Discussion}

Although the limited information available did not permit statistical analysis of the strength-test data, certain trends were indicated.

\section{a. Room-Temperature Strength Tests}

Fairly good agreement was noted for the values of compressive and transverse strength of the bodies (see tables 7 and 8). Those porcelains having the highest compressive strengths also showed the highest transverse strengths, and similarly, the lowest compressive strength bodies showed the lowest transverse strengths.

\section{b. Room-Temperature-Elasticity Tests}

Young's modulus of elasticity at room temperature (table 8) was determined by both sonic and static methods, using bar specimens with a span of 5 in. Unfortunately, the sonic apparatus was not used before the bars had been broken transversely, and it is, therefore, impossible to compare the values obtained by the two methods for the same test specimen. However, it was found that the values obtained by the sonic method were consistently only between 1 and 3 percent higher than those obtained by the static method for different specimens of any given composition. Such agreement is considered as being good. When bars of one composition were tested, for which a 3-in. span was used, the agreement was poor.

\section{c. Transverse Strength at Room Temperature Versus Transverse} Strength at Elevated Temperature $\left(1,800^{\circ} \mathrm{F}\right)$

The transverse strengths at $1,800^{\circ} \mathrm{F}$ were ordinarily about 50 percent lower than the values for specimens of the same body composition tested at room temperature (table 8). Those having the highest strengths at room temperature (with one exception) had only medium or low strength at $1,800^{\circ} \mathrm{F}$, but those with the lowest strengths at room temperature also had the lowest strengths at $1,800^{\circ} \mathrm{F}$.

\section{d. Elasticity at Room Temperature Versus Elasticity at Elevated Temperature $\left(1,800^{\circ} \mathrm{F}\right)$}

Young's modulus values from data obtained at $1,800^{\circ} \mathrm{F}$ were ordinarily 25 to 40 percent lower than the values for specimens of the same body tested at room temperature (table 8). Poor agreement was noted for the relative elasticity values at the two test temperatures. This may have been caused, in part, by the fact that the $1,800^{\circ} \mathrm{F}$ test values were calculated from the lowest part of the deformationload diagrams where the "plastic flow" was relatively small; the deformation of any one bar was not a linear function of the loading of the bar, except for those specimens of mole composition $1 \mathrm{BeO}: 1 \mathrm{Al}_{2} \mathrm{O}_{3}: 1 \mathrm{TiO}_{2}$. e. Stress-Strain Relations Versus Strength and Elasticity at Elevated Temperatures $\left(1,800^{\circ} \mathrm{F}\right)$

Except for the bodies of mole composition $9 \mathrm{BeO}$ : $1 \mathrm{Al}_{2} \mathrm{O}_{3}: 9 \mathrm{TiO}_{2}$, the strain rates for the beryllia-alumina-titania porcelains at $1,800^{\circ} \mathrm{F}$ and $12,000 \mathrm{lb} / \mathrm{in}^{2}$ stress (tables 8 and 9) were only about 10 to 25 percent of the values for beryllia porcelains in the system beryllia-alumina-zirconia [4]. It was possible to compare the stress-strain and strength values of the beryllia-alumina-titania porcelains only at stresses between 6,000 and $9,000 \mathrm{lb} / \mathrm{in} .{ }^{2}$. In this stress range, it was noted that there was good agreement between the strain rates and the transverse strength, that is, those bodies showing very little or no strain ordinarily had the highest transverse strengths, and those with the highest strain rates had the lowest transverse strengths. A similar agreement was noted for the strain-rate-modulus-of-elasticity relations.

When the strain rates of the short-time stressstrain tests at $1,800^{\circ} \mathrm{F}$ were high (above 1.9 (in./in.)/ min at $6,000-\mathrm{lb} / \mathrm{in}^{2}{ }^{2}$ stress and above 2.6 (in./in.) $/ \mathrm{min}$ at $9,000-\mathrm{lb} / \mathrm{in}^{2}{ }^{2}$ stress) the relatively slow loading rate, $\left(1,500 \mathrm{lb} / \mathrm{in} .^{2}\right) / \mathrm{hr}$ of the stress-strain test resulted in transverse-strength values as much as 35 percent lower than those obtained with the more rapid loading, $\left(1,500 \mathrm{lb} / \mathrm{in} .^{2}\right) / 2 \mathrm{~min}$, of the regular transverse strength test. The strength values obtained for specimens that had strain rates lower than those indicated were within 3 to 4 percent of each other, regardless of the loading method used. A 5-percent deviation is considered as good agreement.

\section{f. General Discussion of the Porcelains Developed}

It is believed that three of the body compositions developed in this investigation $\left(15 \mathrm{BeO}: 5 \mathrm{Al}_{2} \mathrm{O}_{3}: 1 \mathrm{TiO}_{2}\right.$, $6 \mathrm{BeO}: 1 \mathrm{Al}_{2} \mathrm{O}_{3}: 2 \mathrm{TiO}_{2}$, and $3 \mathrm{BeO}: 2 \mathrm{Al}_{2} \mathrm{O}_{3}: 1 \mathrm{TiO}_{2}$ ) may find use in high-temperature applications where strength, but not thermal-shock resistance, is of prime importance. The properties determined for these three bodies are compared in table 10 to the range of properties determined for all of the beryllia-alumina-titania porcelains developed.

The high compressive-strength value for the $3: 2: 1$ composition was totally unexpected because the normal crystallization of chrysoberyl would suggest considerably lower strength. This and the 15:5:1 body had the lowest strain rates determined for these porcelains. Of particular interest to those concerned with strength at high temperatures would be the $1: 1: 1$ body; no loss in transverse strength (about $17,000 \mathrm{lb} /$ in. $^{2}$ ) was observed at $1,800^{\circ} \mathrm{F}$ when compared with the value determined at room temperature. However, the 1:1:1 body had a high elasticity - 43 million $\mathrm{lb} / \mathrm{in}^{2}{ }^{2}$ at room temperature and 36 million $\mathrm{lb} /$ in. $^{2}$ at $1,800^{\circ} \mathrm{F}$.

The expansion characteristics of the three highest strength bodies, $15 \mathrm{BeO}: 5 \mathrm{Al}_{2} \mathrm{O}_{3}: 1 \mathrm{TiO}_{2}, 6 \mathrm{BeO}: 1 \mathrm{Al}_{2} \mathrm{O}_{3}$ : $2 \mathrm{TiO}_{2}$, and $3 \mathrm{BeO}: 2 \mathrm{Al}_{2} \mathrm{O}_{3}: 1 \mathrm{TiO}_{2}$, are very s milar to that shown by curve 3 of figure 8 . It is possible to 


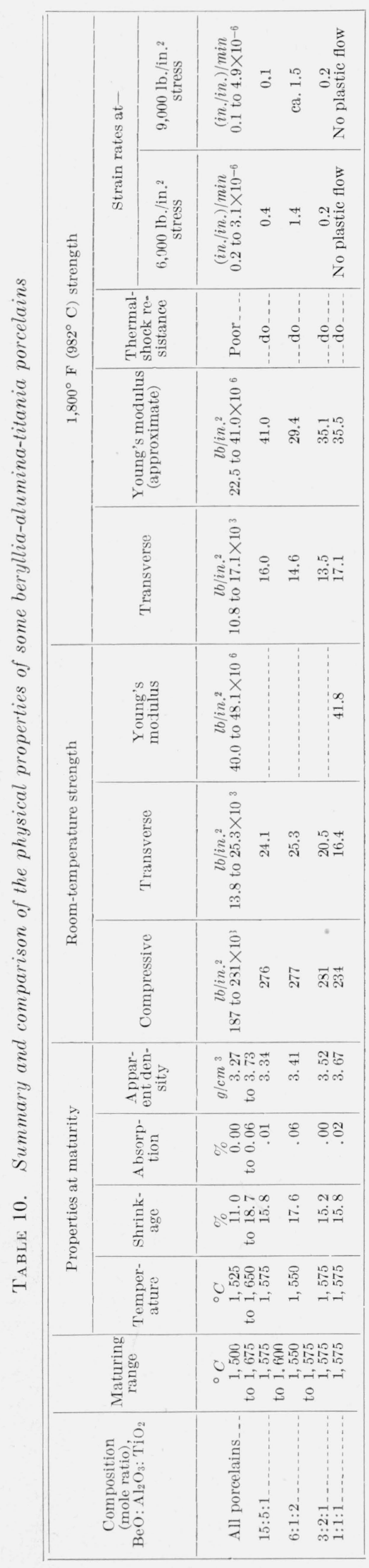

correlate the expansions of the porcelains reported with the expansions of the primary phases for the fields in which these compositions are located.

From the phase relations existing in the system beryllia-alumina-titania (figs. 5 and 6 ), it can be seen why an aluminum titanate-beryllia porcelain of outstanding thermal-shock resistance cannot be developed. A study of the diagram shows that an addition of beryllia to aluminum titanante, and at the expense of the aluminum titanate, forms chrysoberyl, which is noted for its high expansivity, very coarse crystallization, and rather low strength. A similar examination shows also that no free beryllia, for thermal-conductivity benefits, could be available until more than about 20 weight percent of beryllia had been added, and that before that percentage had been reached no low-expansivity aluminum titanate can be formed.

\section{Summary}

The system beryllia-titania contains no compounds, a single eutectic exists at about 85 weight percent of $\mathrm{TiO}_{2}$ and $1,670^{\circ} \pm 3^{\circ} \mathrm{C}$, and a narrow region of mixed crystals (an area of solid solution), as indicated by the melting behavior of various mixtures, extends from just beyond the eutectic to the melting point of pure titania.

Three eutectics in the system beryllia-alumina were found to be at: (1) $1,890^{\circ} \pm 10^{\circ} \mathrm{C}$ and about mole ratio $1 \mathrm{BeO}: 4 \mathrm{Al}_{2} \mathrm{O}_{3}$, (2) $1,850^{\circ} \pm 10^{\circ} \mathrm{C}$ and about mole ratio $2 \mathrm{BeO}: 3 \mathrm{Al}_{2} \mathrm{O}_{3}$, and (3) $1,835^{\circ} \pm 10^{\circ} \mathrm{C}$ and about 75 weight percent of alumina. The melting point of the recently reported compound $\mathrm{BeO}$.$3 \mathrm{Al}_{2} \mathrm{O}_{3}$ was found to be congruent at $1,910^{\circ} \pm 10^{\circ} \mathrm{C}$, and that of chrysoberyl $\left(\mathrm{BeO} \cdot \mathrm{Al}_{2} \mathrm{O}_{3}\right)$ was redetermined at $1,870^{\circ} \pm 10^{\circ} \mathrm{C}$.

In the system alumina-titania, it is probable that the compound $\mathrm{Al}_{2} \mathrm{O}_{3}$. $\mathrm{TiO}_{2}$ possesses two forms. The alpha, or high-temperature, form is stable from the alpha-beta inversion temperature of $1,820^{\circ} \pm 10^{\circ} \mathrm{C}$ to its congruent melting point of $1,860^{\circ} \pm 10^{\circ} \mathrm{C}$. The beta, or low-temperature, form seems to be stable for periods up to $100 \mathrm{hr}$ from room temperature to about $750^{\circ} \mathrm{C}$ and from about $1,300^{\circ} \mathrm{C}$ to its inversion temperature. One eutectic at $1,705^{\circ}$ $\pm 5^{\circ} \mathrm{C}$ and about 20 weight percent of alumina and one at $1,840^{\circ} \pm 10^{\circ} \mathrm{C}$ and about mole ratio $5 \mathrm{Al}_{2} \mathrm{O}_{3}$.$4 \mathrm{TiO}_{2}$ were found in the system. There is some doubt as to whether the alpha aluminum titanate melts congruently or incongruently, but the majority of the data indicate that the melting is congruent.

Although aluminum titanate exhibits low linear thermal expansion, only friable, very low-strength bodies can be made by using the pure component oxides with no other additions. When such a body is used at temperatures between about $750^{\circ}$ and $1,300^{\circ} \mathrm{C}$, a gradual increase in the expansivity can be expected, which can be traced to the decomposition of the aluminum titanate into its constituent oxides.

Three invariant points are indicated in the system beryllia-alumina-titania: (1) $1,572^{\circ} \pm 5^{\circ} \mathrm{C}$ and about mole ratio $2 \mathrm{BeO}: 1 \mathrm{Al}_{2} \mathrm{O}_{3}: 2 \mathrm{TiO}_{2}$, (2) $1,577^{\circ}$ 
$\pm 5^{\circ} \mathrm{C}$ and about mole ratio $2 \mathrm{BeO}: 1 \mathrm{Al}_{2} \mathrm{O}_{3}: 4 \mathrm{TiO}_{2}$, and (3) $1,580^{\circ} \pm 5^{\circ} \mathrm{C}$ and about mole ratio $1 \mathrm{BeO}$ : $1 \mathrm{Al}_{2} \mathrm{O}_{3}: 1 \mathrm{TiO}_{2}$. It is probable that another invariant point is located at about $1,755^{\circ} \pm 10^{\circ} \mathrm{C}$ and about mole ratio $2 \mathrm{BeO}: 5 \mathrm{Al}_{2} \mathrm{O}_{3}: 2 \mathrm{TiO}_{2}$. These invariant points were located in that area of the triaxial diagram representing mixtures containing less than 18 weight percent of beryllia.

Early in the development of the beryllia-aluminatitania refractory porcelains and after the investigation of the phase relations existing in the ternary system, it was evident that any attempt to combine the high thermal conductivity of beryllia with the low expansivity of the compound aluminum titanate could not be successful. However, a number of relatively high-strength high-temperature porcelains were developed. They may be of use in applications where thermal-shock resistance is not of prime importance. The range of values for the general physical properties of practically impervious porcelains of this system were found to be: maturing range, usually $1,525^{\circ}$ to $1,575^{\circ} \mathrm{C}$, but with some of the high-alumina-containing bodies maturing between $1,600^{\circ}$ and $1,700^{\circ} \mathrm{C}$; apparent density, 3.3 to $3.7 \mathrm{~g} / \mathrm{cm}^{3}$; shrinkage, 11 to 19 percent; roomtemperature compressive strength, 187,000 to 280,000 $\mathrm{lb} /$ in. $^{2}$; room-temperature transverse strength, 13,700 to $25,000 \mathrm{lb} /$ in. $^{2}$; Young's modulus at room temperature, $42,000,000$ to $47,000,000 \mathrm{lb} / \mathrm{in}^{2}$; transverse strength at $1,800^{\circ} \mathrm{F}\left(982^{\circ}\right), 10,500$ to $17,000 \mathrm{lb} /$ in. $^{2}$; approximate Young's modulus at $1,800^{\circ} \mathrm{F}, 22,000,000$ to $41,000,000 \mathrm{lb} / \mathrm{in}^{2}$; relative thermal-shock resistance, poor; and, the linear thermal expansion of a few selected bodies, in the range $25^{\circ}$ to $950^{\circ} \mathrm{C}$, usually was regular and ranged from 0.81 to 0.89 percent.
The authors acknowledge the assistance of Howard E. Swanson and Barbara Sullivan in the preparation and interpretation of the X-ray powder diffraction patterns and for the differential thermal analyses.

\section{References}

[1] R. F. Geller and P. J. Yavorsky, J. Research NBS 34, 395 (1945) RP1649.

[2] R. F. Geller, P. J. Yavorsky, B. L. Steierman, and A. S. Creamer, J. Research NBS 36, 277 (1946) RP1703.

[3] S. M. Lang, L. H. Maxwell, and R. F. Geller, J. Research NBS 43, 429 (1949) RP2034.

[4] S. M. Lang, L. H. Maxwell, and M. D. Burdick, J. Research NBS 45, 366 (1950) RP2147.

[5] S. M. Lang and R. F. Geller, J. Am. Ceram. Soc. 34, 193 (1951).

[6] F. B. Hornibrook, Am. Soc. Testing Materials Bul, No. 101, p. 5 (Dec. 1939); and Gerald Pickett, Am. Soc. Testing Materials Proc. 45 (1945).

[7] H. von Wartenburg, H. J. Reusch, and E. Saran, Z. anorg. allgem. Chem. 230, 257 (1937).

[8] E. C. Henry, Pennsylvania State College, Quarterly Progress Report, Memorandum Report No. 19 (Feb. 15, 1949).

[9] H. von Wartenburg and H. J. Reusch, Z. anorg. allgem. Chem. 20\%, 1 (1932).

[10] W. R. Foster and H. F. Royal, J. Am. Ceram. Soc. 32, 26 (1949)

[11] E. N. Bunting, BS J. Research 11, 725 (1933) RP619,

[12] Private communication from F. Hummell, Pennsylvania State College, State College, Pa. (1949).

[13] M. Hamelin, Bul. Ceram. Soc. (France) 11, 14 (1951).

[14] The system beryllia-alumina-titania: Phase relations and general physical properties of three-component porcelains, S. M. Lang, C. L. Fillmore, and L. H. Maxwell, Final Report to Office of Naval Research, ONR Project NR 032-074, Contract NA ori 2-47, Code N-423 (March 30, 1951). Not available for general distribution.

Washington, November 23, 1951. 